\title{
UM ESTUDO DA EVOLUÇÃO DA SENTENÇA NO TRANSCURSO DOS TEMPOS, ATÉ SUA PRÁTICA NO DIREITO PORTUGUÊS ANTIGO
}

\section{Carlos Silveira Noronha ${ }^{1}$}

\section{CONSIDERAÇÕES PRELIMINARES}

Ao ser iniciado o presente trabalho, faz-se mister seja salientado que o foco e a preocupação a serem empreendidos estarão fixados na evolução da sentença, o que implica pesquisar, reexaminar e repensar a projeção deste instituto decisório, no transcurso dos tempos, ao cumprir o seu relevante papel de deslindar os litígios e restabelecer a harmonia entre os litigantes.

E, para conceber-se a historiografia do instituto da sentença no andar dos tempos, trazem-se à baila as ma- nifestações de consagrados juristas acerca do tema histórico. A primeira delas é a de Henri de Page, segundo a qual: “A história do direito é muitas vezes tratada com um condescendente desdém por aqueles que entendem ocupar-se apenas do direito positivo. Os juristas que se interessam por ela, quase sempre à custa de investigações muito longas e muito laboriosas, são frequentemente acusados de pedantismo. Uma apreciação deste gênero não beneficia aqueles que a formulam. Quanto mais avançamos no direito civil, mais constatamos que a história, muito mais do que a lógica ou a teoria, é a única capaz de

1 Professor titular de Direito Civil no Curso de Pós-Graduação stricto sensu da Faculdade de Direito da UFRGS; mestre e doutor em Direito pela Universidade de São Paulo (USP); advogado em Porto Alegre. 
explicar o que as nossas instituições são as que são e porque é que são as que existem". 2

Entre nós, Pontes de Miranda ensina: "O valor dos estudos históricos para o conhecimento do direito vigente assenta em que não se pode conhecer o presente, sem se conhecer o passado; não se pode conhecer o que é, sem se conhecer o que foi. Não se poderia situar, no tempo, na evolução jurídica, cada enunciado do sistema lógico, nem se poderiam fixar certos conceitos, nem se determinariam certas categorias, que têm seus limites marcados pelos fios históricos. Ainda onde o direito mudou muito, muito se há de inquirir do que não mudou. $\mathrm{O}$ direito muda muito onde em muito deixou de ser o que era". ${ }^{3}$

E esta advertência do preclaro mestre não escapou, também, a aguda percepção de Clóvis do Couto e Silva, segundo a qual: "Para se conhecer a situação atual de um sistema jurídico, ainda que em suas grandes linhas, é necessário ter uma ideia de seu desenvolvimento histórico, das linhas de influência que lhe marcaram as soluções no curso dos tempos". ${ }^{4}$

Passando-se à abordagem do tema específico do presente trabalho, que se ocupará do reexame da historiografia do instituto da sentença, porfiada em sua andança nos tempos, cabe registrar prioritariamente a concepção da doutrina clássica, de que a atividade processual se constitui sob a forma e o conteúdo de uma relação jurídica. E as posições doutrinárias que lhe têm sido opostas ainda não obtiveram, até agora, a fortuna de infirmá-la completamente, não chegando algumas delas a transpor a esfera propositiva.

A teoria da relação jurídica, no âmbito processualista, surgiu na Alemanha, há mais de dois séculos, com Oskar von Büllow, por meio de sua obra Excepciones Procesales y Presupuestos Procesales, na tradução espanhola, caracterizando-se como relação jurídica trilateral ou triangular, por ser constituída por três sujeitos principais: juiz, autor e réu, e apresentar as singularidades especiais de contar em sua composição com a pre-

2 DE PAGE, Henri. Traité de Droit Civil Belge, Tome VI, Bruxelles, 1942. In: GILISSEN, John. Introdução Histórica ao Direito, Introdução, p. 13. Trad. por: A. M. Hespanha e L. M. Macaista Malheiros. Lisboa: Ed. Fundação Calouste Gulbenkian, 1985.

3 PONTES DE MIRANDA, Francisco Cavalcante. Tratado de Direito Privado, Parte Geral, Tomo I, Prefácio, p. XV, Edição Borsoi, Rio de Janeiro, 1970.

4 COUTO E SILVA, Clóvis Veríssimo do. O Direito Civil Brasileiro em Perspectiva Histórica e Visão de futuro. In: Revista Ajuris da Associação dos Juízes do Rio Grande do Sul, ano XIV, julho de 1987, n. 40, p. 128, Porto Alegre. 
sença do Estado-juiz, que a preside, ordena e a decide e, ainda, apresentar as peculiaridades de ser dinâmica, evolutiva, continuada e progressiva, no sentido de alcançar o escopo final de solucionar o litígio e esbater a discórdia entre os litigantes. ${ }^{5}$

Para o autor dessa teoria, surgida em meados do século XIX, revela o processo, por sua própria composição e temática, constituir um actum trium personarum e a sua criatura aparece no elenco das instituições jurídicas em geral, não para alterar seus métodos, negar seus princípios ou desviar seus fins. Contrasta, porém, sua estrutura com a da relação jurídica material, por cuja constituição concorrem dois sujeitos que, em tese, são o sujeito ativo ou titular do direito, objeto de sua pretensão, e o sujeito passivo, obrigado ao cumprimento do dever ou da obrigação em sentido estrito, este com o mesmo escopo final de solucionar a relação jurídica material que entre os interessados se trava.

Por outro lado, a relação processual tem origem e constrói sua base e seus fundamentos no complexo estrutural da relação jurídica material, pois dela emerge em razão da situação desarmônica gerada no seio da mesma, pela desinteligência dos sujeitos que a compõem. E, note-se, a relação ma- terial é formada pelos mesmos sujeitos, pessoas naturais ou jurídicas que, diante da desinteligência gerada entre ambos, tornam-na patológica e carente da tutela judicial que lhe é oferecida pelo Estado, abdicando as partes da tutela substancial que se encontra construída no âmago da própria relação jurídica material.

Em realidade, no curial contexto para implementar as soluções das relações jurídicas, convivem, congeminam-se e compartimentam-se as duas vias de tutela dos direitos: a tutela substancial e a tutela judicial. Esta, regulada e expressamente positivada no sistema estatal, classificada segundo a natureza do bem jurídico do respectivo titular ou de outros bens da vida, pertinentes à sua pessoa, que vêm, em última ratio, realizarem-se mediante o exercício da função coercitiva do Estado-juiz.

Por outro lado, dispõem as partes da tutela substancial, que é prioritária, porque reside no complexo contexto de direitos, deveres ou obrigações que se abrigam na própria relação de direito material. E esta, embora não seja nominada, nem explicitamente disciplinada na lei nacional, ao nosso ver, por omissão do sistema pátrio, encontra-se implicitamente presente na nossa ordenação e se pratica cotidiana

5 Ver BULLOW, Oskar von. Excepciones Proesales y Presupuestos Procesales, trad. espanhola, p. 1-9, Buenos Aires: Ediciones Juridicas Europa-América (EJEA), 1964. 
e sistematicamente, tanto na persecução do cumprimento espontâneo do dever ou da obrigação, pelo obrigado, e da satisfação do direito do respectivo titular, por meio da tutela substancial direta, como mediante a efetivação da tutela substancial indireta, na qual o procedimento se opera pela colaboração do sujeito titular do direito, ou sujeito ativo na relação jurídica material, em acordo com o obrigado, ou sujeito passivo na mesma relação.

Mas, no sistema jurídico brasileiro, embora assista prioridade à tutela substancial para resolver a demanda, pelas razões suprarreferidas, não poderá esta atuar em tal sentido, quando a solução dos problemas enfrentados pelas partes apresentarem graus de complexidade e de dificuldade de solução de tal jaez, que venham a tornar imprópria ou inviável a solução suasória pela via da tutela substancial, por não dispor esta, insertos nos seus elementos persuasivos e exortativos, o poder de convencimento dos contendores para ajustarem a composição amigável necessária à solução do litígio. E, nesta hipótese, deverá operar- -se a tutela judicial, em substituição à tutela substancial. ${ }^{6}$

É que na relação processual, que tem seu nascedouro na situação de patologia enfrentada pela relação material, ingressa o outro sujeito principal e necessário, do Estado-juiz, para outorgar àquela o poder estatal coercitivo e, assim, impelir a parte vencida ao cumprimento do dever ou da obrigação. Acerca dessa assertiva, assim se manifesta Pontes de Miranda: "O processo não é mais do que o corretivo da imperfeita realização automática do direito objetivo"”. Esta é também a doutrina de Dinamarco, sobre esse tema. ${ }^{8}$

Assim, em realidade, a própria composição e inteireza de qualquer sistema normativo estatal de tutelas, deve estruturar-se, necessariamente, por esta forma bipolarizada dos canais de tutela substancial e de tutela judicial, com o escopo de oferecer efetividade e segurança quanto ao cumprimento espontâneo, negociado ou coativo das relações jurídicas travadas entre os cidadãos nacionais, devendo obviamente, abranger os in-

6 Acerca da divisão da tutela consubstancial e Judicial, ver, NORONHA, Carlos Silveira. "Repensando a Tutela dos Direitos". In: Revista da Faculdade de Direito da UFRGS. v. 32, p. 76-99. Porto Alegre: Editora Sulina, 2014.

7 PONTES DE MIRANDA, Francisco Cavalcante. Comentários ao Código de Processo Civil de 1973. Tomo I, p. 100. Rio de Janeiro: Editora Forense, 1973.

8 DINAMARCO, Cândido Rangel. Tutela Jurisdicional. In: Separata da Revista Forense, v. 334, p. 254, Rio de Janeiro: Cia. Editora Forense. 
teresses do titular do direito, e correspectivamente, os do obrigado ao cumprimento do dever ou da obrigação.

Referência especial, nesse particular, merece o Código Civil da Itália, que dedica o Livro VI, integrado pelos artigos 2.643 a 2.969 , para a disciplina "Della tutela dei diritti", sede em que distingue as tutelas substancial e jurisdicional. ${ }^{9}$

\section{UMA BREVE IDEIA DE SENTENÇA}

Etimologicamente, o vocábulo sentença vem do verbo latino sentire e, segundo alguns, teria derivado de sentiendo, gerúndio desse verbo, donde a expressão sententia no Direito Romano. Diante de tal origem, não se torna tarefa difícil conceber que a semântica da palavra envolve o sentimento ou a sensibilidade de quem se encontra diante de determinado fato, com o encargo de defini-lo, valorá-lo e atribuir-lhe um comando jurídico. ${ }^{10}$
Todavia, na década dos anos trinta do século passado, Enzo Enriques, em substanciosa monografia, na Itália, concebe a sentença como fato jurídico stricto sensu, em contraposição ao ato jurídico desta mesma categoria. ${ }^{11}$ Este autor peninsular foi seguido por Eduardo Couture, no Uruguai, em duas de suas obras publicadas, uma em $1973^{12}$ e a outra em $1976^{13}$, concebendo a sentença como um fato jurídico e como documento que emerge de raciocínio crítico-intelectivo, mediante o qual o Poder Judiciário elege a solução que entender mais conforme com o direito e a justiça. Também na Itália, proclama Calamandrei não constituir-se a sentença em ato de exatidão ao teor das ciências exatas, nem num juízo de pura lógica formal, mas é mais que isso, porque no conteúdo da equação silogística estão insertos valores morais que participam da vida humana e que não devem ser ignorados. E em razão dessa profunda visão humana, este insigne processualista italiano considera a sentença "Il

9 ITÁLIA. Codice Civile e Leggi Collegate: Della Tutela dei Diritti. Libro Sesto. Bologna: Ed. Zanichelli, 2007. p. 446-491

10 NORONHA, Carlos Silveira. Sentença Civil: Perfil Histórico-dogmático. São Paulo: Edição Revista dos Tribunais, 1995. p. 274.

11 ENRIQUES, Enzo. La Sentença come Fatto Giuridico. Padova, Itália: CEDAM, Casa Editrice Dtt. Antonio Milani, 1937-XV.

12 COUTURE, Eduardo J. Fundamentos del Derecho Procesal Civil. 3. ed. n. 176-186. Buenos Aires: Ediciones Depalma, 1973. p. 277-297.

13 COUTURE, Eduardo J. Vocabulário Jurídico. Buenos Aires: Ediciones Depalma, 1976. p. 537-538. 
cuore del organismo processuale”, na página 12 , da obra abaixo referida. ${ }^{14}$ Já Alfredo Rocco, em obra publicada em 1985, entende ser a sentença o ato estatal aplicador da norma abstrata ao caso concreto, visando a proteção de um determinado interesse. ${ }^{15}$

Em sua generalidade, os autores modernos definem a sentença como $o$ ato judicial através do qual o juiz aplica a regra abstrata, contida na lei, ao caso concreto que lhe é submetido pelas partes, e o faz mediante uma atividade cognitiva, intelectiva e lógica declarando a norma de conduta a ser observada pelos contendores: ao autor, para praticar os atos de poder visando fazer valer o seu direito, se favorável lhe for o ato sentencial, ou abster-se de tal atitude, se desfavorável lhe for a decisão estatal; ao réu, para submeter-se ao ato de poder do autor, ou manter-se inerte em relação àquele, se a sentença acolher a sua própria defesa.

\section{A SENTENÇA NOS ANTIGOS RELATOS HISTÓRICOS}

Abandonado o largo período histórico anterior, e se o faz por razões temáticas pertinentes a este trabalho, chega-se ao primeiro sistema jurídico relativamente organizado de que se tem notícia. Comentam os historiadores acerca de uma civilização que teria vivido nos territórios hoje ocupados pelo Iraque e Irã, aproximadamente 4.500 a 4.800 anos anteriormente à era cristã, formando um Estado chamado Suméria. Nessa organização se poderia constatar os primeiros traços da entidade estatal, como é concebida nos tempos atuais.

Tal civilização estabelecera regras sobre sistemas de leis, ouro, moedas, crédito, joias, literatura, astronomia etc. Todavia, foi submetida pela guerra ao povo babilônico, sob o império de Hamurabi. Vencidos os sumérios, teria o vencedor aproveitado as experiências dos dominados para promulgar no ano 2400 ou 1790 a.C., o Código de Hamurabi, considerado pelos tratadistas do direito antigo o monumento jurídico mais importante da antiguidade antes de Roma, promulgado por Hamurabi, rei da Babilônia, provavelmente, segundo outro entendimento, entre os anos de 1726 e 1686 a.C., com seu texto realizado por volta do ano de 1694, estando gravado numa estela descoberta em Susa, em 1901, e atualmente conservado em Paris, no Museu do Louvre. A codificação

14 CALAMANDREI, Piero. Opere Giuridiche. v. I. Napoli, Itália: Ed. Morano Editore, 1965. p. 11-54.

15 ROCCO, Alfredo. La Sentencia Civil. Tradução espanhola. n. 12 México: Cardenas Editor y Distribuidor, 1985. 
compreende 282 artigos, mas muitas outras disposições foram igualmente encontradas em tabuinhas de argila, de um manejo mais prático.

No fim do texto está declarado: "Hamurabi, rei do direito, sou eu a quem Samas, o grande juiz dos céus e da terra, ofereceu leis e estas são, portanto, de origem divina”. O que é aproveitado em baixo-relevo faz pensar em Jeová entregando o Decálogo a Moisés.

Mas, enquanto o direito de Israel como os da Índia e do Islão são direitos religiosos, dados por Deus, o direito babilônico é, sobretudo, um regulamento da paz, no qual o rei aparece como justiceiro e protetor dos fracos entre os quais os órfãos, as viúvas e os pobres, pois ele deve garantir a liberdade de cada um. Assim, o direito babilônico da época apresenta certas analogias com o direito proveniente do momento de paz dos séculos XI e XII da Europa Ocidental, refere John Gilissen. ${ }^{16}$

O Código de Hamurabi e os numerosos atos da prática no mesmo período proporciona aos juristas o conhecimento de um sistema jurídico muito desenvolvido para a épo- ca, sobretudo no domínio do direito privado, notadamente a respeito dos contratos. Os mesopotâmicos praticaram a venda, inclusive a crédito; o arrendamento de instalações agrícolas, de casas e serviços; o depósito; o empréstimo a juros; o título de crédito à ordem, com cláusula de reembolso ao portador; e o contrato social. Eles realizavam operações bancárias e financeiras em grande escala e tinham já a comandita de comerciantes. Graças ao desenvolvimento da economia de troca e das relações comerciais, o direito da época de Hamurabi criou a técnica dos contratos, ainda que os juristas não tivessem chegado a construir uma teoria abstrata do direito das obrigações. Da Babilônia, esta técnica dos contratos espalhou-se por toda a bacia do Mediterrâneo. Os romanos herdaram-na, finalmente, e conseguiram sistemalizá-la. ${ }^{17}$

O Código de Hamurabi, embora não contivesse inteiro disciplinamento sobre a ordem processual, assim mesmo, em algumas passagens, referia-se à organização dos juízos, procedimento judicial e extrajudicial, tarifamento probatório etc. Sobre a sentença, dispunha expressamente que esse ato

16 GILISSEN, John. Introdução Histórica ao Direito. Tradução de A. M. Hespanha e L. M. Macaista Malheiros. Lisboa: Ed. Fundação Calouste Gulbenkian, 1985. p. 61-62. 17 GILISSEN, John. Op. cit., p. 63-64. 
judicial poderia ser escrito ou oral, recomendando a sua justiça e estabelecendo pesadas penas pecuniárias ao seu prolator em caso de erro, além de declará-lo impedido para funcionar em outros processos (art. $5^{\circ}$ ).

A sentença, nessa codificação babilônica, impunha severas penas pecuniárias, privativas da liberdade e até a pena capital para quem furtasse bens de Deus e da Corte (arts. $7^{\circ}$ e $8^{\circ}$ ).

A sentença, por outro lado, que condenasse alguém por furto de um escravo ou de uma escrava pela porta da cidade, imputava ao culpado a pena capital (art. 15). ${ }^{18}$

\section{A HISTÓRIA DA SENTENÇA NOS SISTEMAS DA ANTIGUIDADE CLÁSSICA}

Para o exame e as manifestações acerca de institutos jurídicos e de experiências relativas ao conhecimento histórico-científico de outras áreas, os estudiosos habituaram-se a fixar suas investigações no período denominado, por alguns, como antiguidade clássica composta por Grécia e Roma.

\subsection{A sentença na Grécia antiga}

A Grécia antiga, considerada pátria da cultura universal daqueles tempos, como berço de filósofos, historiadores e teatrólogos, não deixou celebridades de maior expressão no campo da ordem jurídica. À exceção dos nomes de Licurgo e Solon, nessa área, e de Demóstenes, na oratória, poucos são os outros juristas gregos que se destacaram nesse setor do conhecimento humano. Porém, na falta de construções dogmáticas mais apuradas não se tolhia a civilização helênica de cultivar uma profunda consciência de justiça, que se amparava menos na dogmática jurídica, mas, todavia, em arraigados conteúdos éticos, perenemente hauridos e cultivados pelo povo, nas obras filosóficas, na história e na arte dramática.

A Grécia, como o Egito, não deixou grandes produções jurídicas, nem vastas codificações. Mas, com os grandes pensadores, sobretudo Heródoto, Platão e Aristóteles, fundou-se no país helênico a ciência política ou ciência de governo da polis ou cidade, e ela foi, desse modo, a base importante do nosso direito público moderno. ${ }^{19}$

18 Código de Hamurabi. Uberaba, Minas Gerais: Editora Vitória; ALCALÁ-ZAMORA Y CASTILLO, Niceto. Estúdios de Teoria General e Historia del Processo, Tomo II, p. 295-296; PRATA, Edson. História do Processo Civil e sua Projeção no Direito Moderno, Rio de Janeiro: Ed. Forense, 1987. p. 17-22.

19 GILISSEN, John. Op. cit., cap. 2, p. 52. 
No plano jurídico, não havia na Grécia antiga um estatuto unitário, apto para congregar, em sua generalidade, os princípios e fundamentos estruturais de um sistema global. Havia apenas uma pluralidade de leis particulares de cada cidade, que versavam tanto sobre direito público como privado, com caracteres específicos e evolução própria. Dentre essas instituições particulares destacavam-se apenas as de três cidades: a de Atenas, pelos numerosos escritos literários, a de Esparta, graças à curiosidade dos Antigos e a de Gortina, graças à epigrafia.

O direito das cidades gregas não parece ter sido formulado nem sob a forma de textos legislativos, nem sob a de comentários de juristas, pois, o direito derivaria mais de uma noção mais ou menos vaga de justiça que estaria difusa na consciência coletiva. ${ }^{20}$

A organização judiciária grega era bastante complexa. Nas instâncias superiores havia três tribunais, sendo dois deles com competência partilhada heterogeneamente entre matéria administrativa e jurisdicional. Eram estes a Ecclésia, a Boulé e a Heliéia.

A Ecclésia foi o primeiro órgão na instância superior da organização judiciária grega que atuava praticando um singular procedimento. Em regra, a composição do respectivo colégio julgador abrangia a totalidade dos cidadãos gregos, escolhidos mediante sorteio, preferentemente entre operários e comerciantes, que se reuniam dez vezes por ano. Presidiam-na os Prítanes, magistrados supremos das cidades gregas. Como competência especial, a Ecclésia desfrutava de um limitado poder legislativo. No século V, o exercício dessa competência do órgão acontecia raramente, porém, era-lhe outorgado o poder de fazer decretos que suplementassem as leis.

A Boulé era uma corte judiciária especializada. A sua competência era restrita, havendo certo compartilhamento com a competência da Ecclésia. Mas à Boulé era conferida competência judiciária para julgar funcionários nos casos de malversação e prevaricação e, ainda, uma competência administrativa para examinar e censurar registros de estado civil, de cavalaria, de assistência pública, de superintendência das finanças e dos trabalhadores públicos, assim como os problemas de construção e conservação dos edifícios públicos. Todavia, exerceu sempre seus atos de governo de pleno acordo com a Ecclésia.

A Heliéia estava na organização judiciária da Grécia antiga entre os tribunais populares, e era o órgão de direito comum competente para julgar todos os processos não atribuídos a

20 GILISSEN, John. . Op. cit., p. 75. 
outros tribunais, exercendo, portanto, um tipo de competência residual no complexo organizativo grego. Por outro lado, exercia a alta função de julgar os processos encaminhados pela Éfese, isto é, quando um cidadão opunha-se, por meio de um veto, à aplicação de uma decisão que lhe fosse contrária, quer por julgamento de outro tribunal quer em decisão do Areópago (tribunal cuja sede foi, por largo tempo, na coluna de Ares-Areios págos) ou dos membros dos Onze, ou da sentença de um magistrado.

Em suma, esses atos dos tribunais e juízes tornavam-se aplicáveis e exequíveis se o demandado vencido se conformasse com tais decisões. Apresentada a oposição, por Éfese, de outro cidadão, era lícito também atacar esse veto, e tal situação ensejava a criação de outro processo a ser julgado pela Heliéia.

O tribunal da Heliéia era constituído por uma fração da Ecclésia. A integralidade do órgão era dividida em dez seções denominadas dicastérios, isto é, câmaras ou tribunal pleno e, no século $\mathrm{V}$, o número de heliastas era de 6.000, sendo que em cada ano eram sorteados 600 de cada tribo de uma lista elaborada pelos habitantes da localidade, podendo dela participar todo e qualquer cidadão grego. Os heliastas designados prestavam juramento de julgar segundo as leis, de maneira imparcial, não podendo aceitar presentes.
A organização da Heliéia foi modificada no ano 376, quando os Heliastas passaram a fazer parte dos juízes permanentes, tornando-se vitalícios.

Na Grécia antiga, a justiça era popular, sendo os juízes pessoas do povo, escolhidos dentro de suas tribos para um mandato de um ano. Contudo, a partir de 376 os Heliastas (juízes da Heliéia) passaram a ser vitalícios. Havia apenas a exigência de que contassem 30 anos de idade.

O processo era iniciado com petição escrita, obedecendo essa forma até a instrução, diante do juiz instrutor, perante o qual também devia ser tentada a conciliação. Não alcançada esta, remetia-se o processo ao tribunal da tribo respectiva, que realizava os debates e prolatava o julgamento mediante votação secreta e por maioria simples, sob a presidência do juiz instrutor.

$\mathrm{Na}$ organização processual da Grécia antiga, até o século IV, todos os procedimentos que transitavam pela área civil, como na área criminal, eram praticados pela forma escrita, pautando-se pela forma oral a partir do século V. O julgamento nos tribunais realizava-se após os debates dos profissionais de acusação e defesa, não necessariamente por advogados. Após os debates, os juízes décastés decidiam a causa por maioria, mediante votos secretos. O julgamento, que era oral, tinha o seu resultado proclamado pelo presidente do órgão jul- 
gador, sendo posteriormente reduzido a escrito pelo escrivão.

A sentença era, no processo grego, o pronunciamento judicial que decidia a questão principal acerca do caso posto em julgamento perante o colegiado. Era a sentença, assim proferida, soberana e irrevogavelmente, estando sujeita apenas à concessão de graça pelo tribunal da Ecclésia. Era prolatada oralmente e reduzida a escrito pelo escrivão, isso a partir do século $\mathrm{V}$, quando todo o procedimento pautou-se pela oralidade, substituindo a forma escrita que foi operada até fins do século IV. ${ }^{21}$

\subsection{A história da sentença nas instituições romanas}

Realizada, ainda que brevemente, a análise dos estilos comportamentais e os objetivos acerca do instituto da sentença nos sistemas sócio-jurídicos mais longevos, não há que se constatar nos mesmos influência sensível na vivência moderna dessa instituição que colima resolver o litígio e restabelecer a harmonia entre os contendores. Mas, no período da chamada antiguidade clássica, surgiu e organizou-se o sistema romano que se projetou historicamente ao criar e coordenar seu próprio sistema jurídico, concebendo e disciplinando uma plêiade de institutos jurídicos que até hoje são acolhidos e praticados no mundo ocidental, dentre os quais figura o da sentença.

Historicamente, Roma foi fundada, como cidade-estado, no ano 753 a.C., segundo a opinião mais autorizada de historiadores. Politicamente, em sua longa história, o império romano foi dividido em três períodos distintos, correspondendo, de igual modo, a três regimes políticos diferentes: a Realeza, da fundação da cidade-estado no ano e 753 até 509 a.C., sendo governada pelos dois primeiros monarcas, o lendário Rômulo e Numa Pompílio; a República, aproximadamente a partir do ano 509 até 87 a.C.; e o Império, a partir do ano 27 a.C. até 284 d.C., com Diocleciano (284-305), subdividindo-se este em Alto Império, de 27 a.C. até 284 d.C. e em Baixo Império, de Constantino (306-337)

21 UCHOA CINTRA, Geraldo de. História da Organização Judiciária e do Processo Civil. v. I. p. 9-32. Rio de Janeiro; São Paulo: Editora Jurídica e Universitária Ltda., 1970. Sobre a organização judiciária grega ver também: PAOLI, Ugo Enrico. Studi Sul Processo Áttico. Padova: Ed. CEDAM, 1933. p. 4-5; BISCARDI, Arnaldo. Diritto Greco Antico. Milano: Ed. Giuffrè, s/data. p. 170-173; p. 270-272; AZEVEDO, Luis Carlos de. O direito de ser citado. São Paulo: Ed. FIEO - Editora Resenha Universitária, 1980. p. 71. 
até Justiniano (525-566), da era Cristã, e se projetou politicamente perante o mundo de então desde o século VII a.C. até o século VI d.C., ao tempo de Justiniano, no Oriente. ${ }^{22}$

Juridicamente, segundo a historiografia mais autorizada, a atuação do direito romano perdurou durante 22 séculos, ou seja, no período em que exerceu politicamente o domínio sobre os territórios conquistados, desde o século VII a.C. até o século VI d.C., no tempo de Justiniano (525566), como referido acima. Prolongou-se, ainda, a atuação das instituições jurídicas romanistas no império bizantino do oriente, e no ocidente a ciência jurídica romana conheceu um renascimento deveras significativo a partir do século XII da era cristã, de modo que permaneceu consideravelmente efetiva a sua influência sobre todos os sistemas romanistas modernos de direito, notadamente os sistemas europeus continentais filiados à chamada família Civil Law. ${ }^{23}$

O primeiro estatuto jurídico instituído em Roma, foi a Lei das XII Tábuas, provavelmente no ano 450 a.C., que tem sido referida pelos historiadores por lei decenviral, porque elaborada pelos decenviri, os 10 cidadãos romanos mais respeitáveis e considerados mais sábios naquele estágio temporal da Urbis. E, anteriormente à elaboração daquele estatuto legal, o processo judiciário para decidir as demandas ocorridas entre os cives ou quirites, estes habitantes de Roma, realizava-se mediante um procedimento inorgânico, como ius non scriptum, cuja decisão era proferida por sacerdotes em nome da divindade, com base nos costumes praticados pelos Mos Maiorum, ou seja, pelos cidadãos mais acatados da cidade-estado. Esse sistema judiciário, que perdurou durante todo o período político da Realeza e se estendeu, segundo historiadores romanistas, por mais de três séculos até os primórdios da República, extinguiu-se a partir do momento em que os sacerdotes foram substituídos por magistratus publici populi romani, que não mais passaram a julgar em nome da divindade, mas em nome do povo romano, eis que eleitos pelos romanos para o exercício de um mandato de um ano. O primeiro magistrado eleito seria o praetor urbanus, criado no ano 367 a.C., porque o praetor peregrinus teria sido criado no ano 240 a.C.

Ao ver de certos autores, como Carlo Augusto Cannata, a transformação do iuditium sacramentale pelo

22 GILISSEN, John. Op. cit., p. 80-84.

23 GILISSEN, John. Op. cit., p. 80. 
iuditium laicum trouxe grandes vantagens ao processo da época, pois substituiu o procedimento sacramental sob a regência dos sacerdotes, limitado ao utrius saramentum iustum, utrius iniustum sit, com participação mínima das partes na investigação da verdade, pelo procedimento laico, mais racional, introduzindo-se a peroratio dos advogados na instrução probatória e o debate oral perante o juiz com objetivos decisionais. ${ }^{24}$

Efetivamente, com a vigência da Lei das XII Tábuas, o sistema judiciário romano foi dividido em três grandes períodos, o da legis actiones, o do formulário o per fórmulas ou per concepta verba e o da cognitio extra ordinem.

\subsubsection{A instrumentalidade da sentença nas ações das lei}

No regime das legis actiones, a atividade processual era exercida por meio de modelos prefixados na Lei (Lei das XII Tábuas, do ano 450 a.C.), constituídos, segundo revela Gaio, pelas seguintes ações: legis actio per sacramentum, legis actio per iudicis arbitrive postulationem, legis actio per condictionem, legis actio per manus iniectionem e legis actio per pignoris capionem.

Segundo Gaio, a actio sacramentum era a de emprego mais generalizado que qualquer das outras, sacramenti actio generalis erat (Inst. 4.3). ${ }^{25}$ Essa generalização, além de torná-la a mais importante, significava que qualquer pretensão ou qualquer situação podia ser ajuizada pelas formas do sacramentum, eis que o seu rito era adequado para qualquer situação. Assim, esta ação era exercitada sempre que a lei não tivesse previsto outra, segundo Gaio (4.13), pois só era limitada pelo conteúdo e pelo escopo das demais ações. ${ }^{26}$

Como se pode notar, a descrição gaiana não se reporta à expressão mais antiga do processo per sacramentum. E é essa a primeira manifestação do processo sacramental, cuja existência não se pode negar, que revela a mais profunda generalidade a que se refere Gaio. ${ }^{27}$

24 CANNATA, Carlo Augusto. Profilo Istituzionale del Processo Privado Romano. I Legis Actiones. n. 22. Turim: Giappichelli Editore, 1980. p. 61-62.

25 GAIO, Instituciones. Ed. Bilíngue (latim-espanhol); trad. espanhola por Manuel Abellan Velasco e outros. Madri: Ed. Civitas, 1985. p. 307-309.

26 GIOMADO, Anna Maria. La Tipicitá delle Legis Aziones e la Nominatio Causae. Milano: Ed. Giuffrè, 1988. p. 4; notas 4 e 5.

27 LÉVY-BRUHL, Henri. Recherches sur les Actions de la Loi. Paris: Edicion Sirey, 1960. p. 37 e ss.; BISCARDI, Arnaldo. Lezioni sul Processo Romano Antico e Classico. Turim: Giappichelli Editore, 1968. p. 66 e 77. 
Além da actio sacramentum as duas seguintes, na ordem acima especificada, figuravam como ações de cognição, enquanto as duas últimas eram ações de execução, mais tarde substituídas pela actio iudicati, isto a partir da humanização do processo executivo através da Lex Poetelia Papiria, aproximadamente em 326 a.C. ${ }^{28}$

Nesse período, o processo era rigorosamente formalístico, devido ao fato de que as ações da lei estavam estritamente ajustadas às palavras contidas no texto legal e, por isso, imutáveis, obrigando as partes a observá-las literalmente. Essa característica foi de certo modo justificada por Ihering sob o argumento de que o formalismo é o palladium da liberdade (Gaio, inst. 4.11).

Dividia-se o iter processual em duas fases: in iure e apud iudicem, e isso passou a ocorrer, segundo alguns autores, a partir do momento em que os sacerdotes, que vinham exercendo funções judiciárias há mais de dois séculos, foram substituídos por magistratus publici populi romani, que julgavam não mais em nome da divindade, mas em nome do povo romano. $^{29}$

A cisão dos dois procedimentos decorria de um ato solene - a litiscontestatio - que não era nem um contrato nem uma novação, mas que da sua existência, já então no período das ações da lei, não se pode duvidar, segundo a opinião de tratadistas autorizados (Scialoja e Luzzatto). ${ }^{30}$

Após, o processo passava às mãos do iudex unus, ou de juízes agrupados nos collegia, tais como o dos "recuperatores" constituído por pessoas do povo, à semelhança dos jurados modernos e os tribunais permanentes, que podiam ser dois, às vezes três: centumviri, decemviri e triumviri. $\mathrm{O}$ primeiro era o mais importante, o segundo com atuação menos frequente e do último se tem notícia por uma referência feita por Tito Livio.

A sentença definitiva que deslindava o litígio e encerrava o processo de cognição, não sofria qualquer influência da litiscontestatio, porquanto esta era de caráter meramente formal e declaratório, razão porque não operava qualquer modificação da situa-

28 ARANGIO-RUIZ, Vicenzo. Instituciones de Derecho Romano. Trad. esp. Buenos Aires: Ed. Depalma, 1952. p. 157.

29 CRUZ e TUTTI, José Rogério. Jurisdição e Poder. São Paulo: Edição Saraiva, 1987. p. 16-17; COSTA, Emilio. Storia delle Fonti del Diritto Romano. Milano; Turim; Roma: Fratelli Bocca Editori, 1909. p. 46.

30 SCIALOJA, Vittorio. Corso di Istituzioni di Diritto Romano. Roma: Ed. Anonima Editoriale, Roma, 1934. p. 195-196; LUZZATTO, Giuseppe Ignacio. Procedura Civile Romana: Parte II, legis Actiones. Bolonha: Ed. UPEB del Dott. Cesare Zuffi, 1948. p. 311-314. 
ção jurídica enfrentada pelas partes, pois seus caracteres não condiziam com os de uma sentença de condenação, segundo Cannata. A tal conclusão pode-se chegar por meio de uma expressão de Gaio (institutas 4.48), quando este explica que a condenação nas ações e sentenças do processo clássico recaia sempre numa soma em dinheiro, ao inverso do que se costumava fazer no passado. Assim, para Cannata, o advérbio de tempo olim, empregado por Gaio, que tem o significado de "passado" ou de "outrora”, é uma referência clara às legis actiones, nas quais, consoante o comentário deste jurisconsulto, não havia condenação. ${ }^{31}$

\subsubsection{O plano da sentença no sistema formular}

O processo formulário ou per formulas ou per concepta verba, recebeu da doutrina romanista a qualificação de "clássico" em razão do método que o fez nascer como processo próprio da ciência jurídica romana laica, ou seja, aquela que, se desenvolvendo em certo período e militando sob a disciplina de determinado método, recebeu essa mesma qualificação, assim como as legis actiones representavam a ciência jurídica de conteúdo divino ou pontifical para o período histórico anterior. Este sistema tem o seu primeiro gérmen nos albores da República, juntamente com a jurisciência laica matura-se durante séculos de república - quando perfeccionou seu próprio método - e atinge o ápice de sua expansão no epílogo desse estilo de governo do povo romano e acaba por conviver com a nascente cognitio extra ordinem com Dioleciano (285-305), ao final do terceiro século da era cristã. ${ }^{32}$

O surgimento desse novo sistema não resultou de uma concomitância puramente cronológica em relação às mudanças político-sociais e econômicas experimentadas pela realidade romana, mas sofreu uma forte influência da orientação e do método seguidos por uma casta de juristas que nos estudos jurídicos da época entenderam de imprimir à criação e interpretação dos direitos subjetivos. Assim, se ao teor da definição de Celso (D. 44,7, 51) o direito da ciência clássica era um sistema de ações e o processo formular significava o aparato proces-

31 CANNATA, Carlo Augusto. Profilo del Processo Privato Romano. n. 20. Turim: Ed. Giappichelli Editore, 1982. p. 51-57.

32 Sobre essa síntese descritiva do sistema per formulas no complexo do Ordo: CANNATA, Carlo Augusto. Profilo del Processo Privato Romano. II Processo Formulare. n. 1. Turim: Ed. Giappichelli Editore, 1982. p. 1-2. 
sual próprio de tal sistema de ações, este procedeu-se com um altíssimo tecnicismo substancial de definição das pretensões e de um reduzidíssimo tecnicismo procedimental, segundo a opinião de Cannata. ${ }^{33}$

A criação do processo formular (agere per concepta verba) está ligado a dois eventos legislativos ocorridos, respectivamente, no terceiro quartel no século II a.C. e no segundo decênio da era Cristã. Efetivamente, com a edição da Lex Aebutia, entre os anos 149 e 126 a.C., passou-se a permitir a utilização do processo formulário como forma alternativa mais moderna, menos formalística, mais ágil e funcional a ser utilizada nos casos para os quais não estava prevista uma actio legis do sistema então em vigor. A partir das leges Juliae e, especialmente, da Lex Julia iudiciorum privatorum no ano 17 a.C., restou proscrito o sistema das ações da lei, tornando-se obrigatório o sistema formular mediante a substituição da $a c$ tio pela formula, redigida pelo pretor com a colaboração das partes. ${ }^{34}$

De um modo geral, os romanistas costumam fundar a adoção do sistema formular nas limitações constatadas na vivência prática do sistema anterior. Além de sua aplicação restrita aos cidadãos romanos, deixando desprovidos de tutela a plebe e os estrangeiros, contava ainda com elenco limitado de ações - apenas cinco, sendo três de conhecimento e duas de execução -, deixando, inclusive, em razão dessa limitação, de tutelar alguns interesses dos próprios cidadãos romanos para os quais o sistema das legis actiones não encontrava solução, não só por inexistência de uma actio própria, mas também devido à sua inflexibilidade formal. Assim, segundo a doutrina, as principais causas que fomentaram o aparecimento do sistema per formulas, teriam sido essas duas graves insuficiências das ações da lei.

O processo clássico conservou a divisão do procedimento em duas fases: in iure e apud indicem, cuja partilha já vinha sendo adotada desde o período anterior do lege agere. Mas, o instrumento de cisão que estabelecia um verdadeiro "divisor de águas" entre os dois procedimentos no processo clássico, era a litiscontestatio, ao ensejo da laicização do procedimento das legis actiones, quando a jurisdição pontifical foi substituída pela jurisdição laica, consoante posi-

33 CANNATA, Carlo Augusto. Profilo del Processo Privato Romano. II Processo Formulare. n. 1. p. 2; n. 2. p. 3-4. Turim: Ed. Giappichelli Editore, 1982.

34 CANNATA, Carlo Augusto. Profilo del Processo Privato Romano. II Processo Formulare. n. 12-14. p. 46-67; e espec. p. 58. Turim: Ed. Giappichelli Editore, 1982. 
ção doutrinária de reconhecida autoridade a que se filia o professor José Rogério Tucci, da USP. Esta corrente alude, como um dos argumentos em que embasa a sua convicção, o fato da criação do praetor urbanus em 367 a.C., salientando que não seria lógica a divisão do procedimento perante os pontifices, porque, se a litiscontestatio que aí se operasse, não passaria de um ato meramente formal, sem conteúdo substancial, e, portanto, sem nenhuma eficácia sobre a res in indicio deducta (ver nota 32, supra).

Efetivamente, a litiscontestatio do procedimento do agere per concepta verba, ou formulário, é bem distinta da que ocorria no sistema anterior das ações da lei. A expressão litiscontestatio, tem origem na época arcaica do sistema das legis actiones e vem de construção semântica semelhante, a contestari litem, enunciada por Festo: contestari litem dicuntur duo aut plures adversarii, quod ordinato iudicio utraque pars dicere solet: testes estote. Nesse estágio, o dito ato constava de um cerimonial solene de uma legis actio realizado com a presença de testemunhas (testes), chamadas para controlar o empenho ou a manifestação de vontade das partes perante o magistrado, de remeter à pronúncia do juiz a sua controvérsia e a esta se submeterem. ${ }^{35}$ Encerrava-se aí o procedimento correspondente à fase in iure, das ações da lei, com o ato da litiscontestatio, através do qual não se operava nenhuma modificação na situação substancial, de modo a novar a res in iudicio deducta, pois esta se trasladava para a fase in iudicio em sua versão originária. A litiscontestatio do período per formulas era diferente. Era o ato através do qual, sem a presença de testemunhas, o demandado aceitava a fórmula redigida pelo pretor, a pedido do autor, na qual se espelhava a controvérsia sustentada pelas partes em face da versão por estas oferecida ao magistrado (res in iudicio deducta), bem como a indicação do juiz (dare iudicem). Com este ato, em que as partes convencionavam acerca do conteúdo da fórmula, dos limites da controvérsia e dos cometimentos atribuídos pelo magistrado ao juiz e que afinal era por aquele aprovado, encerrava-se a fase in iure do processo formular. ${ }^{36}$

35 Sobre a litiscontestatio, no sistema arcaico: COSTA, Emilio. Profilo Storico del Processo Civile Romano. Roma: Ed. Athenaeum, 1918. p. 39-40.

36 Acerca da litiscontestatio no processo formular: COSTA, Emilio. Storia delle fonti del Diritto Romano. Milão; Turim; Roma: Ed. Fratelli Bocca, 1909. p. 40-41; CANNATA, Carlo Augusto. Profilo del Processo Privato Romano. II Processo Formulare. n. 4. p. 7-11; n. 3. p. 163-165; n. 40. p. 175-181. Turim: Ed. Giappichelli Editore, 1982. 
A fórmula do pretor era composta por partes essenciais e acessórias. Essenciais eram a demonstratio, a intentio, a adiudicatio e a condemnatio (Gaio, 4.39); acessórias eram as exceptiones, as praescritiones, a replicatio, a duplicatio e a triplicatio (Gaio, 4.126-129).

Na demonstratio como a própria expressão está a indicar, o autor fazia a enunciação do fato que constituía o fundamento do litígio. Na intentio expunha-se a pretensão e a sua abrangência, de modo a que fossem revelados os limites da controvérsia e se estabelecesse a res in iudicio deducta; e na condemnatio o pretor manifestava o seu poder de ordenar a condenação ou a absolvição do demandado, com o escopo de alcançar-se um resultado tendente à satisfação do direito através da execução. Com tais objetivos, eram incluídas na fórmula as seguintes expressões dirigidas ao iudex: $\mathrm{Si}$ paret (tudo o que se contém na demonstratio e na intentio), condemna; Si non paret, absolve (Gaio, IV, 43).

Esses elementos inseridos no conteúdo da fórmula faziam com que a litiscontestatio produzisse efeitos de ordem substancial e de ordem processual.
Os efeitos substanciais decorriam do fato que, declarada na demonstratio com todas as suas especificações, a relação jurídica ou a obrigação em torno da qual se havia gerado o litígio e deduzida na intentio a pretensão do autor relativamente ao seu direito, ocorria uma consumação da situação anterior, transfundida na fórmula em situação nova, devido à convenção em tal sentido realizada pelas partes perante o pretor. Realizada a fórmula, subsumia-se nela a obrigação originária, em razão da novação que aí se operava, cujos efeitos eram de ordem substancial. A maioria dos romanistas entende que esse ajuste modelador da relação jurídica anteriormente estabelecida entre os sujeitos e tornada patológica pela desavença, tem a natureza e os efeitos de novação. Assim já a proclamava Gaio, em suas Institutas (IV, 180 e 181), incluindo-se nessa mesma linha ponderável parcela da doutrina romanista. ${ }^{37}$

Esse fato da consumação do direito anterior na fórmula que era objeto da litiscontestatio e que o absorvia completamente, impedia o credor de voltar a propor a realização de qualquer outra maneira de efetivar o seu direito, porque a litiscontestatio, além da sua

37 Dentre muitos outros: COSTA, Emilio. Ibidem. p. 41-42; SCIALOJA, Vittorio. Procedimiento Civil Romano. Trad. esp. de Santiago Sentís Melendo e Marino Ayerra Redin. § 30. Buenos Aires: Ediciones Juridicas Europa-América (EJEA), 1954. p. 235-240. 
eficácia material ou substancial, gerava ainda um impedimento a um novo processo, ou um non bis in idem, fato que no direito moderno chamamos “proclusão processual”. Este, o efeito processual que daquele importante ato do sistema formular resultava. ${ }^{38}$

A sentença definitiva no processo formulário era essencialmente de condenação, devido à cláusula alternativa hipotética contida na intentio e ratificada na condemnatio, segundo a qual Si paret, condemna; si non paret, absolve (Gaio.IV; 41 e 43), pois só a condenação levava à efetiva satisfação do direito, devendo tal condenação ser em dinheiro. Isso só não ocorria quando o iudex unus ou os collegia não conseguiam formar um convencimento firme acerca dos fatos e do diretio do autor, quando podiam abster-se de julgar mediante juramento da cláusula sibi non liquere, providenciando o pretor na substituição do juiz ou dos membros dos Collegia dos recuperatores, centumviri, decenviri, quando substituíam o iudex unus em tal situação. ${ }^{39}$
A sentença definitiva, como antes se referiu, era de natureza condenatória no processo formular ao pagamento de uma quantia em dinheiro.

Na prolação da sentença, não estava o juiz sujeito a formas solenes como no período anterior, não havendo nem sequer exigência de motivá-la, pois seu dever limitava-se a exercitar o iussus indicandi recebido do magistrado, pronunciando o comando si paret, condemna; si non paret, absolve. O professor José Rogério Cruz e Tucci, com arrimo em Biondi, concebe uma atividade intelectiva no livre convencimento do juiz que diz com o elemento lógico, presente na proposição da fórmula gaiana si paret, non paret, enquanto no seu resultado condemna, absolve (Gaio, IV, 43) está o comando jurídico que confere ao ato a eficácia desejada. É deste, segundo a distinção de Biondi, que emerge a obligatio iudicati em favor do autor vencedor. ${ }^{40}$ Passado o tempus iudicati de trinta dias, estava o autor habilitado a promover a execução, mediante a propositura da actio iudicati, por-

38 Sobre o efeito processual da litiscontestio: CANNATA, Carlo Augusto. Op. cit., n. 40, p. 175-181.

39 SCIALOJA, Vittorio. Procedimiento Civil Romano. Trad. espanhola. v. I. Buenos Aires: Edificiones Jurídicas Europa-América (EJEA), 1949. p. 131-139.

40 Sobre a estrutura lógico-funcional da sentença: BIONDI, Biondo. Appunti Intorno alla sentenza nel Processo Civile Romano. In: . Scritti Giuridici II. Direito Romano. Milano: Ed. Giuffrè, 1965. p. 442-448; CRUZ e TUCCI, José Rogério. A Motivação da Sentença no Processo Civil. São Paulo: Saraiva, 1987. p. 28-31. 
quanto da sententia iudicis não havia recurso no processo privado romano, eis que aí o juiz julgada in nomine populi romani. ${ }^{41}$

Existe certa dúvida na doutrina sobre se a sentença, no período per formulas, era prolatada oralmente ou por meio da escrita. Cannata, pronunciando-se sobre o assunto, conclui pela oralidade: Quale fosse Il regime romano, non è possibile stabilirlo com certezza: ma vari indici suggerirebbero l'oralità della sentenza, al meno per quelle dell'ordo iudiciorum privatorum. ${ }^{42}$

Proferida a sentença, cumpria o juiz e esgotado restava o seu ofício, não podendo mais, em circunstância alguma, ser o ato alterado. Não competia ao iudex realizar a execução por não dispor do poder de imperium que se incluía nas atribuições do pretor.

Como se viu, o modelo primordial de provisão judicial para decidir os litígios entre cidadãos romanos, cives ou quirites, no período per formulas, era mediante uma sentença condenatória, para a prolação da qual o iudex unus ou os collegia fundavam-se no esquema lógico alternativo que lhes era proposto pela fórmula gaiana si paret (sententia), para chegar ao comando jurídico (iudicatum) condemna, absolve (Gaio, IV. 43).

\subsubsection{A projeção da sentença no período da cognitio extra ordinem}

Ainda no período do agere per formulas, desenvolvia-se inteiramente perante o magistrado ou funcionário imperial investido da iurisdictio o processo da extraordinaria cognitio.

Apesar de haver autores que sustentam a coexistência da cognitio extra ordinem desde as primeiras manifestações dos sistemas que a antecederam, afirmando que a mesma foi obra lenta e sucessiva cuja sedimentação se operou por muitos séculos, ${ }^{43}$ a maioria da doutrina entende que a

41 LA ROSA, Franca. L'actio Iudicati nel Diritto Romano Classico. Milão: Ed. Giuffrè, Milão, 1963. p. 53-57. Acerca desse tema, ver ainda o nosso trabalho Actio iudicati. Um instrumento de humanização da execução. In: ÁLVARO DE OLIVEIRA, Carlos Alberto (org.) et alii. O processo de execução: Estudos em Homenagem ao Professor Alcides de Mendonça Lima. Porto Alegre: Ed. Sérgio Antonio Fabris, 1995. p 95-126. 42 Sobre a oralidade ou a escritura da sentença no sistema do "ordo": CANNATA, Carlo Augusto. Op. cit., nota 2, p. 186-187. Turim: Giappichelli Editore, 1982.

43 CUENCA, Humberto. Processo Civil Romano. n. 135; 138. Buenos Aires: Ed. Jurídicas Europa - America, 1957. p. 124-126. 
sua origem esteja nos processos que se desenvolviam nas províncias, onde aos súditos não cidadãos romanos não era acessível o recurso ao processo do agere per formulas do período clássico. A argumentação era ainda a de que os governadores que exerciam as funções jurisdicionais nos territórios por eles governados, acostumados a exercer mais o imperium que propriamente a iurisdictio, pelo despotismo de seus métodos muito frequentemente deixavam de nomear o juiz que no sistema clássico decidia o processo na fase apud iudicem, restando, assim, o mesmo unificado em suas mãos, como iudex unicus, para decidi-lo unipessoalmente. ${ }^{44}$ Essa expansão provincial da cognitio teria ainda como argumento em seu favor a transformação política sofrida por Roma a partir de Constantino, no sentido de que a Urbs deixara de ser Roma-Cidade que obrigava os quirites, para tornar-se a Roma-Estado, plena de estrangeiros que mudavam toda a ordem social e que, em razão disso, vieram a ter seus direitos reconhecidos, principalmente após a constituição do Imperador Caracala, estendendo a cidadania a toda a população.
Segundo a versão mais atual acerca da origem do processo público é que se teria iniciado ao fim do Principado, quando o Imperador, assumindo o poder, pretendeu irradiar a sua autoridade quanto ao mister de administrar a justiça a todas as províncias romanas, delegando-a aos funcionários imperiais; mas, conservando em seu poder, a condição de iudex-Supremus. ${ }^{45}$ Esse argumento tem em seu favor uma máxima de sabedoria milenar divide et imperat, mas encontra também apoio num elemento de psicologia sociopolítica de que toda a autoridade é sequiosa de poder. Esses dados de natureza sociológica e psicológica dão muito conforto a essa corrente de opinião acerca da origem do processo público.

Em 294 d.C., Diocleciano (284305) expediu uma constituição criando os iudices pedaneus que se dirigiam ao local dos litígios para conhecer dos respectivos processos, em iudex unícus, integralmente, desde o libelo até a sentença final, na qualidade de delegados do príncipe, identificando-se já aí, oficialmente, o novo processo das cognitiones extra ordines em plano localizadamente provincial. Questio-

44 LUZZATTO, Giuseppe Ignazio. Il Problema D’Origine del Processo Extra Ordinem. Bolonha: Ed. Casa Editrice Prof. Ricardo Patron, 1965. p. 15-16; COSTA, Emilio. Op. cit., p. 152; ARANGIO RUIZ, Vicenzo. Storia del Diritto Romano. Nápoles: Casa Editrice Dott. Eugenio Jovene, 1985. p. 323-325.

45 PALAZZOLO, Nicola. Processo Civile e Politica Giudiziaria del Principato. Turim: Giappichelli Editore, 1980. p. 57-85. 
nam alguns autores o objetivo real da constituição diocleciana-maximianea, se teria se destinado à abolição da $d a-$ tio iudicis do sistema formulário ou se efetivamente centrava seu escopo numa melhor distribuição de justiça, pela criação dos iudices pedaneus, prevalecendo afinal este último entendimento, isto é, de que com esse ato imperial instalara-se, de direito, a era do processo público. Assim, a cognitio passou a desenvolver-se concomitantemente com o agere per formulas. Porém, na concorrência com o novo sistema, que se mostrava mais acessível ao povo por sua unidade, simplificação e intervenção direta e decidida de um funcionário delegado do Imperador, começou a conquistar as preferências de todos os romanos quirites, cives, non cives e estrangeiros (hostes), até que uma constituição do ano 342 d. C., de Constâncio e Constante (filhos de Constantino), dirigida a Marcelino, governador da Fenícia, ab-rogou completamente o sistema clássico ou per concepta ver$b a$, proscrevendo-o aproximadamente com as seguintes, palavras: "sejam cortadas absolutamente, desde a raiz, as fórmulas de direito insidiosas, verdadeiras sutilezas verbais, em vista do perigo de que, ao errar na forma exterior da fórmula, chegue-se a golpear o verdadeiro conteúdo da relação que se quer fazer valer. ${ }^{46}$

Neste período, o magistrado, que era um funcionário imperial, não agia em nome próprio, mas em nome do imperador de quem havia recebido a delegação, ficando a este subordinado.

Caracterizou-se a cognitio pelo desaparecimento da divisão do processo nas fases in iure e apud iudicem; a administração da justiça passa a ser exclusividade do Estado, sendo o processo dirigido ex auctoritate Principis, coordenado pelo impulso oficial e não mais sujeito ao princípio dispositivo; o magistrado estava obrigado a solucionar o processo, não lhe sendo mais permitido o juramento sibi non liquere, do sistema ordo. Não obstante, embora a litiscontestatio conservasse a mesma nomenclatura do sistema formular, tinha na cognitio caráter apenas formal, sem conteúdo substancial. A citação do demandado não era mais realizada pelo autor, mas pelo magistrado, sendo o processo instaurado com o libellus convencionis do autor, comunicando-se o ato ao réu pelo executor do magistrado mediante ato equivalente à in ius voca-

46 SCIALOJA, Vittorio. Op. cit. § 50, p. 365-368; BETTI, Emilio. Istituzioni di Diritto Romano, v. I, § 102-103. Padova: Ed. CEDAM, 1941. p. 346-351; DE FRANCISCI, Pietro. Sintesis Historica del Derecho Romano. Trad. espanhola de Ursicino Alvarez. Madri: Ed. Revista de Derecho Privado, 1954. p. 595-599. 
tio. O demandado poderia discordar pelo libellus contradictiones, devendo comparecer perante o magistrado no prazo de dez dias, aumentado para 20, por Justiniano e, não comparecendo, o réu seria considerado contumaz. A prova continuava a ser tarifada, dando-se grande importância aos documentos públicos ou particulares, admitindo-se as presunções absolutas.

A sentença definitiva, julgadora da demanda, era prolatada pelo magistrado, condenando ou absolvendo o demandado após a produção e valoração da prova, porquanto as questões prévias já haviam sido resolvidas no andar do processo. Todo o objeto principal da demanda deveria ser abrangido pela sentença final, mas poderia ser ampliada a via procedimental na hipótese de reconvenção do réu, admitida pelos romanos a partir da constituição C.7.45.14 e a Novela 96.2.1, quando se tratasse do mesmo negócio. ${ }^{47}$

A partir de uma constituição de Valentiniano e Valente, na segunda metade do século IV da era Cristã, a sentença do sistema da extraordinaria cognitio era prolatada por escrito, ato por excelência público porque proferido pelo magistratus populi romani, que evocava a autoridade do príncipe, na pessoa do seu delegado que poderia também ser o prefeito, o governador da província ou o juiz pedâneo, representando o interesse público do Estado romano.

Assim, em muitos pontos divergia a sentença do sistema da cognitio extra ordinem da proferida no âmbito do sistema formulário ou per formulas, pois perante este último a sentença não era mais uma opinião do juiz diante da alternativa condemna, absolve, pois na cognitio era prolatado um provimento jurisdicional do magistrado que aplicava a lei ao caso concreto, aliás, como é na atualidade a concepção generalizada do direito moderno. É que, no sistema da cognitio, a sentença deixou de ser um ato fundado na litiscontestatio, para constituir-se em ato formal declaratório da vontade da lei, emanado do poder de julgar que o magistrado recebia diretamente do príncipe, então executor exclusivo da lei.

Deste modo, proferida a sentença, era emitido um comando imperativo (iudicatum), emergente da vontade da lei, pronunciado por um magistrado funcionário do Estado que se encontrava investido das funções de iurisdictio e de imperium. Com o ato decisório dava-se por cumprida a ati-

47 Quanto à reconvenção no sistema romano: CRUZ e TUCI, José Rogério. Da Reconvenção. São Paulo: Edição Saraiva, 1984. p. 1-11. 
vidade de cognição do magistrado, mas devia permanecer consigo, segundo corrente doutrinária liderada por Eisele (Ueber Actio Judicati, p. 154), a sua atividade executiva, para dar prosseguimento e completar a tutela do direito do credor. ${ }^{48}$

Todavia, poderia o magistrado não se considerar apto para julgar a causa, seja porque havia se apercebido de sua incompetência, seja porque diante da imprecisão de alguns fatos não havia chegado a um convencimento satisfatório acerca da verdade que se buscava perquirir. Nestas hipóteses, era-lhe facultado provocar uma consulta perante o tribunal imperial, mediante comunicação aos litigantes, realizando, no prazo de dez dias, uma síntese completa acerca do estado e das circunstâncias da controvérsia que provocaram esse ato consultivo. Cientificadas do episódio, facultava-se às partes formularem observações e objeções sobre o relato do magistrado, devendo-se encaminhar tudo à apreciação do príncipe, que, em razão disso, reassumia definitiva e com exclusividade a função de julgar a causa.

Essa providência, como se constata, não deixava de guardar similitu- de com o juramento sibi non liquere facultado ao iudex unus e aos membros dos collegia, no sistema anterior per formulas.

Por fim, o que se pode observar no sistema romano, é que o processo translada-se paulatinamente, transformando-se de um sistema privado para um processo público, mediante uma progressiva publicização das funções processuais com reflexos acentuados no conteúdo da sentença.

\section{A HISTÓRIA DA SENTENÇA NO SISTEMA CANÔNICO}

A Igreja Católica caracteriza-se por formar uma sociedade fundada na ordem sobrenatural, constituída por uma comunidade universal de seres humanos que a ela se incorporam pelo sacramento do batismo, passando a formar, a partir daí, o chamado povo de Deus. Dotada, no plano humano, de estrutura semelhante a do Estado, embora com este não se identifique, no plano espiritual possui a Igreja o poder de instituir as suas próprias leis para definir o comportamento, os direitos e deveres da comunidade cristã que a compõe.

48 Mais recentemente, a teoria de Eisele foi seguida por CUENCA, Humberto. Processo Civil Romano. Op. cit., n. 166, p. 172-174. 
Duplo papel exerce a Igreja: o de instituição divina e sobrenatural como criação do próprio Deus, para cumprir os seus desígnios; e como entidade terrena, temporal e profana, emergente da própria contingencialidade social e humana do homem no concerto do universo. Embora o aparente antagonismo entre os dois papéis, no exercício da função divina, de ordem sobrenatural, e no desempenho da ação humana, na ordem terrena, na realidade ambas não se repelem, antes se integram e se completam.

E no complexo da realidade terrena, a postura assumida pela canonística, especialmente na convivência com as instituições romanas, veio oferecer subsídios para a formação do moderno direito europeu-continental, filiado à chamada família $\mathrm{Ci}$ vil Law, como afirmam historiadores especializados. ${ }^{49} \mathrm{E}$ que se estende aos sistemas jurídicos da América Latina em razão dos descobrimentos de ultramar realizados por espanhóis e portugueses.

Embora tenham a doutrina e as codificações canônicas oferecido contribuições a instituições de direito material, notadamente no âmbito do direito de família, às codificações modernas, é no campo da jurisdição e do processo que a canonística tem oferecido paradigmas modelares, ocorridos no andar dos tempos a essa área do direito público estatal. Há que se lembrar que o primeiro órgão judiciário, na esfera canônica, foi a episcopalis audientia, ou tribunal do Bispo, criado no início da cristandade como foro judiciário para julgar as demandas dos fiéis que inicialmente se reuniam nas "masmorras" de Roma, para furtar-se à perseguição imposta aos cristãos pelos imperadores romanos da época; de modo que o dito órgão judiciário canônico só passou a exercer publicamente suas funções a partir de Constantino (306-337), convertido ao cristianismo no Edito de Milão, no ano 313 d.C. ${ }^{50}$

A sentença canônica, que decidia a demanda mediante o procedimento da episcopalis audientia, era proferida in nomine Dei, pelo Bispo (episcopus) que governava uma diocese, cujo procedimento judicial devia ancorar-se no animus e na tranquillitas mentis e, ainda, sujeito ao requisito da certeza moral do seu prolator.

49 MERRYMANN, John Henry. La Tradición Juridica Romano-Canónica. Trad. espanhola de Carlos Sierra. México: Ed. Mexico Fundo de Cultura, 1971. p. 29.

50 ARIAS, José V. Salazar. Dogmas y Cânones de la Iglesia em el Derecho Romano. Madri: Instituto Editorial Réus, 1954. p. 299-304. 


\subsection{A situação peculiar da sentença no Decreto de Graciano}

A seguir, transcorridos cerca de oito séculos, ou seja, do século IV até o século XII da era cristã, surgiu no ano 1140 o Decreto de Graciano, ou simplesmente Decretum, compilação organizada pelo monge Camaldulense Graciano de S. Feliz e Nabor, professor de direito canônico na Escola de Bolonha (ano 1088), auxiliado por Rolando Bandinelli, que, no ano de 1159 d.C., tornou-se o Papa Alexandre III, quando foi, por esse Decreto, inteiramente renovado o tribunal canônico da episcopalis audientia, criado no início da cristandade.

A sentença definitiva, perante o Decretum era o provimento judicial que decidia a demanda travada entre as partes e decretava a fase final do processo de cognição, devendo ainda estar exornada pelos princípios da espiritualidade e da moralidade, pois prolatada in nomine Dei e observado o requisito da certeza moral.
Além da sentença definitiva, que figurava como o principal ato da processualística, as provisões do magistrado ainda incluíam a sentença interlocutória que decidia os incidentes que surgiam no seio dos procedimentos, e o decretum, com o qual era o processo ordenado e desenvolvido. A sentença definitiva era impugnável pela appelatio, tanto as injustas ou iníquas e também as nulas, pois segundo a doutrina de Liebman, por longo tempo tanto no direito romano quanto no direito medieval as sentenças inquinadas de errores in iudicando e as com errores in procedendo, eram passíveis do recurso de apelação, ${ }^{51}$ completando-se a assertiva com Della Rocca, para quem a querella nullitatis, para atacar a sentença nula, só teria surgido da confluência da exceptio nullitatis das Decretais com a actio nullitatis do processo comum. ${ }^{52}$

A sentença interlocutória era apelável no Decreto graciânico por disposição expressa (c.38.q.6.C.II), que a identificava com a sentença definitiva..$^{53}$

51 LIEBMAN, Enrico Tullio. Apunti Sule Impugnazioni. XIII ristampa. Gulliardica, Milão: Ed. Cisalpino, 1961. p. 1-3.

52 DELlA ROCCA, Fernando. Instituciones de Derecho Procesal Canónico. Trad. espanhola. Buenos Aires: Ed. Deselée de Brouwer, s/d. p. 348-349; DELLA ROCCA, Fernando. Saggi di Diritto Processuale e Canónico. Appunti sui Gravami nel Processo Canónico. Padova: Ed. CEDAM, 1961. p. 17.

53 PELLEGRINO, Piero. II Provedimenti Interlocutori nella Teoria Canonistica delle Impugnazioni. Padova: Ed. CEDAM, 1969. p. 17. 
Aliás, tal posição assumida na dita compilação não era de se estranhar, porque essa era a regra no processo canônico desde que, em contato com o processo germânico antigo, teve o seu procedimento dividido em fases estanques, em termini ou estadia, com provisão judicial, que no processo romano chamava-se interlocutio e, no processo canônico, passou a denominar-se sententia interlocutoria.

Para o trânsito em julgado da sentença era exigida uma tríplex sententia conformis, pois quanto a esse requisito a situação da época pré-graciânica se mantinha inalterada, de vez que a triplicidade de sentenças conformes para a duplicidade só ocorreu com a primeira codificação canônica oficial de $1917 .{ }^{54}$

O recurso de apelação para impugnar a sentença definitiva e a sentença interlocutória devia ser formulado no prazo de dez dias, dirigido ao órgão judicial imediatamente superior ao que as havia decidido inicialmente, salvo os recursos para a Sé Apostólica (Rota Romana e Supremo Tribunal da Assinatura Apostólica ou diretamente ao Romano Pontífice), casos em que poderia ser per saltum.

\subsection{As inovações da sentença nas Decretais de Gregório IX}

Outra obra de alta significação no âmbito do direito canónico foram as Decretais de Gregório $I X$, promulgadas no ano de 1234 pelo então Sumo Pontífice Gregório IX, sucessor de Honório (1216-1227) e sobrinho de Inocêncio III (1198-1216), obra organizada a título de consolidação autêntica e exclusiva para reunir e ordenar as respostas pontificais e consultas formuladas pelos Bispos e doutores da cristandade existentes na época. $\mathrm{O}$ encarregado de compilar a obra foi o confessor de Gregório IX e destacado professor de lógica na Escola de Bolonha (1088), o dominicano Raimundo Peñafort, posteriormente canonizado Santo da Igreja. Realizado o trabalho, foi a compilação promulgada por Gregório IX pela Bula Rex Pacificus, de 5 de setembro de 1234, sob o título de Decretais; sendo declaradas universais e exclusivas, revogando todas as compilações anteriores, com exceção do Decreto de Graciano, promulgado no ano de 1140.

As Decretais gregorianas foram também conhecidas por Liber Extra

54 Sobre a tríplice sentença conformes: HENRIQUEZ, Miguélez Moreno. Derecho Procesal canónico. Madri: Ed. Aquilar, 1956. p. 334-336. 
e tiveram grande aceitação, não se limitando a cuidar apenas dos assuntos do clero. Elas influíram, também, nas legislações laicas que surgiram no futuro - os governantes usavam-nas como parâmetro para a elaboração das próprias codificações, devido à unidade, à garantia e à segurança que revelavam em sua estrutura -, quando também passaram a adotar a sistemática das Decretais, de dividir as respectivas codificações em cinco Livros, como ocorre até hoje, tornando-se, assim, a codificação de Gregório IX o parâmetro de grande valia para a formação do direito medieval e também do direito moderno.

Autores há que as consideram “a pedra angular de edifício canônico até o Código". ${ }^{55}$

A obra estava dividida em cinco livros, enquanto a matéria pertinente ao iudicium encontrava-se no Livro II, dividido em 90 títulos e 421 capítulos. No título XXVII, composto por 26 capítulos, eram tratados os institutos da sententia e da res iudicata.

Para iniciar-se o procedimento, o autor comparecia perante o juiz e apresentava-lhe uma postulatio, ordenando-se a citação do réu, a in ius vocatio, para comparecer perante o juiz e apresentar a sua defesa e as provas para sustentar suas razões. Com o libelo do autor e a defesa do réu, chegava-se à litiscontestatio, mas por meio desse ato não se registrava nenhuma convenção entre as partes, para modificar a posição inicial da demanda, como ocorria no processo clássico romano. Desse modo, a litiscontestatio não influía na decisão da demanda.

Realizada e encerrada a fase probatória, o juiz prolatava a sentença definitiva, condenando ou absolvendo o réu, iniciada com a invocação in nomine Dei e ainda exornada pela certeza moral do magistrado, quanto à justiça desse provimento por ele proferido.

A sentença devia ser escrita, pois todos os atos procedimentais nas Decretais obedeciam ao princípio da escritura, ou se em certos casos fossem realizados oralmente deviam reduzir-se a escrito para se perpetuarem nos autos (quod non est in actis, non est in mundo), por exigência da Bula, Quoniam Contra, do ano de 1210, de Inocêncio III (1198-1216), anterior, portanto, às Decretais gregorianas.

A sentença atingia a autoridade de coisa julgada após alcançar três sentenças conformes, fenômeno que a doutrina canônica denominou triplex sententia conformis.

55 MARTINS GIGANTE, José Antonio. Instituições de Direito Canônico. v. I. n. 23. Braga, Portugal: Ed. Escola Tip. da Oficina São José, 1951. p. 27-29. 
A sentença definitiva injusta estava sujeita ao recurso de apelação para o juízo imediatamente superior ao que a havia proferido e, a sentença válida, transitada em julgado se por algum motivo devesse ser rescindida - poderia sê-lo pelo recurso extraordinário da restitutio in integrum.

Devido ao fato do procedimento do sistema canônico dividir-se tradicionalmente em períodos estanques, denominados termini ou stadia, cada uma dessas fases devia encerrar-se com uma sentença interlocutória, que já vinha sendo admitida pela canonística desde o Decreto de Graciano, por disposição expressa (c.38.q.6.C.II), que a identificava com a sentença definitiva. $\mathrm{O}$ processo canônico, em contato com o processo germânico antigo, como já se referiu antes, teve o seu procedimento dividido e encerrado nas duas fases estanques, classificadas como terminum ou stadium, sendo que esse ato judicial, então chamado interlucutio no processo romano, passou a chamar-se sententia interlocutória no processo canônico, tornando a impugnação desta passível do recurso de apelação, dirigido ao órgão judicial imediatamente superior ao que havia inicialmente proferido a decisão, salvo se, em face da categoria especial do tema decidido, fosse determinado pela canonística o cabimento de um dos recursos extraordinários para a Sé Apostólica, já antes mencionados, podendo ser, nessa hipótese, per saltum, o recurso.

No entanto, há autores, como SURGIK, que entendem devesse ser a sentença nula, no regime das Decretais gregorianas, impugnada pelo recurso de cassação, por ser a posição que se coadunava com a doutrina que assimilava um pelo outro instituto. ${ }^{56}$

\subsection{O procedimento de sentença na codificação canônica de 1917}

A Igreja Católica do Ocidente, no âmbito de sua estrutura espiritual e temporal, pratica ou coordena a prática de fatos e atos jurídicos de toda ordem, tanto relacionados com as autoridades eclesiásticas como pertinentes à comunidade de fiéis, recebendo todos a regência da ordem jurídica canônica, situando-se tais fatos no campo direito material ou na seara da processualística.

Diante de tais realidades, a Igreja, desde a sua fundação por Cristo, ao início do principado romano, procurou estabelecer a sua própria conduta normativa. No primeiro milênio e até a obra de Graciano, as fontes do direto canônico eram emanadas das Encíclicas, Bulas papais, ordens dos concílios e em coleções privadas, sendo a última desta categoria, mas modelarmente organizada, o Decreto de Graciano do ano de 1140 d.C. A partir daí, passou a Igreja a tomar o caminho 
da sistematização da normatividade celesiástica, já com a intervenção do Romano Pontífice, expressando uma visão político-religiosa dos seus próprios desígnios. Uma destas foram as Decretais de Gregório IX, antes referidas, seguidas pela compilação de Bonifácio VIII, no ano de 1298, com a denominação de Livro Sexto, para reunir as leis que tivessem surgido após as Decretais gregorianas e, ainda, ocorreu a promulgação da Clementina Saepe Contingit, pelo Papa Clemente V (1305-1314), instituindo o processo sumário, cujo procedimento devia desenvolver-se simpliciter, breviter, de plano ac sine streptu ac figura judicii, publicada pela Bula Clementina Saepe Contingit, em março de 1306 ou em 21 de março de 1314, sendo posteriormente republicada pela Bula Quoniam Nulla de 25 de outubro de 1317 , por João XXII. ${ }^{57}$

Assim, transcorridos cerca de seis séculos da vigência das Decretais gregorianas e das disposições legislativas esparsas que lhe seguiram, chegou a Igreja Ocidental à codificação unificada, sistematizada e autêntica do direito eclesiástico, com a promul- gação do primeiro Codex Canonici de 1917, após quinze séculos de militância terrena, partindo daí para o amadurecimento da ideia de uma codificação unitária e universal, que já fora concebida no Concílio de Trento (1545-1563) e nos Concílios posteriores, e realizada por uma comissão de varões doutíssimos, sob a presidência do canonista Pietro Gasparri. Com a colaboração conjunta de todo o episcopado do universo, o trabalho de codificação estendeu-se por dez anos, estando já quase completo em 1914, quando faleceu Pio X. O Papa Bento XV, seu sucessor, concluiu a obra, anunciando-a ao mundo, pelo Consistorium de 4 de dezembro de 1916, que estava ultimada a codificação, promulgando-a no dia de Pentecostes, pela constituição Providentíssima Mater Ecclesia, de 27 de maio de 1917, com vacatio legis de um ano, havendo entrado em vigor na mesma festa de Pentecostes do ano seguinte, ou seja, em 19 de maio de $1918 .^{58}$

Foram, na codificação, definidos os Tribunais eclesiásticos, sua estrutura, seu grau hierárquico e sua competência, tendo como ato relevante

56 SURGIK, Aloisio. Compêndio de Direito Processual Canônico. Curitiba: Ed. Livro é Cultura, 1988. p. 34 e 380.

57 Acerca dos processos das Decretais de Gregório IX e das demais disposições legislativas esparsas que lhes seguiram: SURGIK, Aloísio. Op. cit., p. 29-36.

58 MARTINS GIGANTE, José Antonio. Op. cit., v. I, p. 29-34. 
de sua promulgação a substituição da multissecular episcopalis audientia pelo Tribunal Ordinário de primeira instância cânones 1.572-1.593). Os Órgãos de segunda instância (cânones 1.594-1.596) eram a Rota Romana e o Supremo Tribunal da Assinatura Apostólica, como instâncias ordinárias e especiais, às vezes extraordinárias, e como Juiz Supremo, situado no vértice da pirâmide hierárquica, estava o Romano Pontífice (cânones 1.597-1.605).

O processo, em sua estrutura funcional, seguia o sistema do direito comum ou romano-canônico, esboçado ao final da Alta Idade Média, a partir do Studium Cívile, de Bolonha (1.088), dominado pela forma escrita (Cânon 1.706), imprimindo-se no procedimento certo rigorismo formal, inquisitoriedade na produção da prova, com a observância dos princípios do segredo e do inquisitivo, a exemplo do que exigiam os evangelhos dos primeiros tempos da cristandade, quando o cristão, para assistir a missa dominical, teria que, antes de tudo, conciliar-se com o irmão desafeto. Também o princípio da conciliação era de exigência fundamental.

O processo judicial era dividido em ordinário, especial e administrativo, devendo ser observado este último com rito sumário para a remoção de párocos (cânones 2.162-2.167); o processo ordinário utilizado para as causas em geral; o especial, para as causas matrimoniais; e, o adminis- trativo, também chamado processo governativo, dizia respeito às causas sobre a beatificação de servos e a santificação de beatos, de competência exclusiva da Sé Apostólica (cânones 1.999-2.141). Também administrativos eram os processos disciplinares contra clérigos irresidentes e concubinários (cânones 2.168-2.181). Aos analfabetos, era deferido o processo oral, devendo a pretensão do autor ser registrada na ata do ofício pelo notário (cânon 1.707) que exercia as funções de auxiliar judiciário.

Os provimentos judiciais dividiam-se em sentenças definitivas, sentenças interlocutórias (cânon 1.868, $\S 1^{\circ}$ ) e decreto, este último definido por critério de exclusão, isto é, era utilizado o decreto para o provimento judicial destinado a resolver questões incidentes que não pudessem ser resolvidas nem por sentença definitiva, nem por sentença interlocutória (Canon $1.868, \S 2^{\circ}$ ).

As sentenças definitivas eram, na vigência da codificação canônica de 1.917, os provimentos judiciais que decidiam as questões principais arguidas pelos litigantes durante $\mathbf{o}$ desenvolvimento procedimental do processo e, para a justiça e eficácia destas, exigia a lei a certeza moral (cânon 1869) do seu prolator acerca da procedência ou não dos temas questionados pelos intervenientes na relação processual; aliás, esse requisito da certeza moral vem sendo exigi- 
do pela canonística desde as Decretais gregorianas, como se viu.

Quando injusta a sentença definitiva era a mesma passível de ser impugnada pelo recurso de apelação (cânon 1.879), mas, quando viciada por errores in procedendo, estava sujeita a impugnação pela querella nullitatis (cânon 1.892), expressamente admitida pela codificação de 1917, espancando-se, desse modo, a dúvida que vinha desde as Decretais gregorianas, do ano de 1.234. Ainda, quando essa decisão sentencial prejudicasse interesse de terceiro, era lícito ao prejudicado impugná-la pelo recurso da oposição de terceiro (cânones 1.898-1.901).

Alcançava a autoridade de coisa julgada, a sentença, quando ocorrida a duplex sententia conformis, reduzindo-se, na codificação canônica de 1.917, a exigência anterior da triplex sententia conformis. Mas a sentença válida, transitada em julgado, estaria sujeita à rescisão por meio da restitutio in integrum, se presentes estivessem os pressupostos integrativos desse reurso extraordinário (cânones 1.905-1.907), isto é, quando a sentença causasse grave dano a um dos litigantes e manifesta a sua injustiça. ${ }^{59}$

Quanto às sentenças interlocutórias, como tais vêm sendo qualifi- cadas pela tradição do direito canônico ao dividir o procedimento em períodos estanques, denominados termini ou stadia, cada uma dessas fases encerrada por uma sentença interlocutória. Assim, a partir das Decretais de Gregório IX, do ano de 1.234, seguindo a tradição, passou a canonística a admitir esse instituto decisório para resolver as questões incidentes surgidas no procedimento, admitindo também a sua recorribilidade mediante o recurso de apelação. Acontece que, segundo tem registrado a história, desde o Concílio de Trento (1545-1563), encontram-se as interlocutiones classificadas em interlocutoriae símplices e em interlocutoriae vim definitivam habentes, cujos cânones daquele conclave foram aprovados pela Bula Renedictus Deus, de 25 de janeiro de 1564, do Papa Pio IV.

Diante de tal situação, a doutrina e a legislação canonista, segundo o disposto no Canon 1.880, § $6^{\circ}$, da codificação de 1917, passaram a acolher o recurso de apelação para impugnar as sentenças interlocutórias com força de definitivas, também chamadas sentenças interlocutórias mistas, assim consideradas as terminativas do processo e as que produzissem dano irreparável ou de difícil reparação ao

59 Sobre a "restitutio in interum" na codificação canônica de 1917, ver DOMINGUEZ, Lorenzo Miguélez et al., Código de Derecho Canónico Comentado. Comentários al cânon 1.906, p. 725, Edición Biblioteca de Autores Cristianos (BAC), Novena Edición, Madri, 1976. 
vencido, mantendo irrecorríveis as sentenças interlocutórias simples.

\subsection{A dinâmica da sentença na codificação canônica de 1983}

Como se tem referido em manifestações precedentes, vem a Igreja Católica do Ocidente renovando as suas leis e as demais disposições canônicas, sempre com a finalidade não só de estatuir instrumentos adequados de autorregulamentação de suas atividades no cumprimento da missão salvadora do povo cristão, como também para continuar a desenvolver um complexo normativo capaz de reger as suas próprias atividades como a dos fiéis. O vigente código canônico de 1983 é a segunda codificação oficial da Igreja Ocidental. Sensível aos desígnios reformatórios que sempre estiveram presentes no corpo da Igreja, vinha o episcopado de todo o mundo advertindo o Romano Pontífice da necessidade de promover-se nova reforma do ordenamento canônico, pois o estatuto então vigente, devido à sua estreita vinculação ao sistema de direito comum emergente da Escola de Bolonha (1088) e de suas disposições mais voltadas para a disciplina exegético-normativo do que propriamente para os conteúdos de direito divino e de direito apostólico, traziam algumas dificuldades ao desempenho dos papéis da Igreja, diante das novas circunstâncias históricas que se abriam à humanidade após o término da Segunda Guerra Mundial encerrada em 1945.

Assim, em 25 de janeiro de 1959, o Papa João XXIII reabriu o Concílio Vaticano I, que anteriormente havia sido suspenso em razão das belicosidades da Guerra franco-prussiana e o fez alterando a denominação daquele conclave para Concílio Vaticano II, com a participação superior a dois mil Bispos de todo mundo.

Decorrido quase quinze anos dos trabalhos de revisão, a nova codificação foi entregue ao Sumo Pontífice, em 29 de junho de 1980, na Festa dos Apóstolos Pedro e Paulo e, realizadas as revisões necessárias, foi o texto novamente editado em 22 de abril de 1982, sendo o novo Codex Iuris Canoníci promulgado por João Paulo II, pela Constituição Apostólica Sacrae Disciplinae Leges, de 25 de janeiro de 1983, na mesma data em que, vinte e quatro anos antes, o Papa João XXIII havia lançado a ideia de criar o Consílio Vaticano II. ${ }^{60} \mathrm{O}$ novo Código entrou em vigor no primeiro dia do Ad-

60 ECHEVERRIA, Lamberto de. et al. Código de Derecho Canónico (de 1983). Prefácio. Ed. comentada bilíngue (latim-espanhol). Madri: Biblioteca de Autores Cristianos, 1985. p. XXXIX até LII. 
vento, na época, em 27 de janeiro de 1983, como determinara a dita Constituição Apostólica que o promulgou. Compõe-se a codificação de 1.752 cânones, sendo mais sintético e concentrado que o estatuto anterior de 1917, que era composto por 2.414 cânones. Divide-se a vigente codificação em sete livros, disciplinando em cada um deles todas as funções, os encargos, direitos e deveres da Igreja, dos clérigos e do tratamento do Povo de Deus, a respeito do qual se destacam as funções de ensinar e santificar.

No que se refere à jurisdição eclesiástica, o Código trata especialmente da organização dos tribunais, pois esses constituem os órgãos da jurisdição da Igreja, encarregados dos misteres do processo canónico. E na linguagem canonística, o vocábulo tribunal não tem a mesma significação da linguagem do direito secular, em que a expressão sempre identifica um órgão colegiado. $\mathrm{Na}$ jurisdição canônica, o tribunal pode ser composto por iudex unus ou por um collegium, segundo as circunstâncias, sendo este colégio formado por clérigos e outros membros, como o relator, o auditor, o assessor, o defensor do vínculo, o notário e o oficial de justiça, embora nem todos tenham a função de julgar. Juiz nato em cada diocese é o Bispo, o qual, além da potestade estritamente judicial, dispõe também da função governativa sobre os tribunais e, em razão disso, dirige o processo, nomeia o relator e os demais auxiliares, fiscaliza e disciplina as atividades do tribunal.

Na primeira instância, está o Tribunal Diocesano ou Tribunal do Bispo (cânones 1.419-1.426), que na codificação anterior de 1917 denominava-se Tribunal Ordinário de Primeira Instância (cânones 1.572-1.593) e que naquele passo substituiu a ultramilenar episcopalis audientia, que vinha operando desde o início da cristandade, figurando como tribunal de primeiro grau. E pode haver um tribunal diocesano para abranger mais de uma diocese (cânon 1.423).

Na segunda instância, situam-se o Tribunal Metropolitano, também chamado Tribunal do Arcebispo (cânones 1.438-1.441), podendo ser designado outro tribunal para julgar a apelação quando o metropolitano tiver decidido a causa como instância originária (cânon 1.438, § $2^{\circ}$ ). O tribunal de segunda instância para o julgamento, em grau de recurso, é sempre colegiado (cânon 1.441).

Na terceira instância estão os Tribunais da Sé Apostólica, constituídos pela Rota Romana e o Supremo Tribunal da Assinatura Apostólica (cânones 1.442-1.445). A Rota Romana muitas vezes se constitui em tribunal ordinário de segunda instância (cânones 1.443-1.444), ou até como tribunal originário de primeira instância nas causas criminais contra os Bispos, bem como nas que o Romano 
Pontífice, tanto motu proprio, como à instância de parte, tenha avocado ao seu tribunal e a tenha encaminhado à Rota Romana para julgamento inicial (cânone 1.444, § $2^{\circ}$ ).

É sempre de instância extraordinária o Supremo Tribunal da Assinatura Apostólica. O Romano Pontífice é o juiz para todo o orbe católico pertinente à Igreja do Ocidente ou Igreja Latina (cânones 1.404 e 1.442).

A processualística, na codificação canônica atual, de 1983, está dividida em contencioso ordinário, em contencioso oral, em contenciosos especiais, em contencioso administrativo e em contencioso penal. Cada qual dos cinco tipos de contenciosos encontram-se discriminados e especificados nos procedimentos constantes nos cânones 1.671 a 1.731 da codificação vigente, dispostos segundo o direito e/ou interesse dos intervenientes nas respectivas demandas, deixando de ser aqui especificados, por não constituírem o principal objeto deste trabalho. Nos atos procedimentais realizados na área processual sob a vigência desta codificação, deve ser obedecido o princípio da escritura, que vem sendo exigido na processualística canônica desde a promulgação da Bula Quoniam Contra, do ano de 1210, por Inocêncio III (1198-1216), anteriormente às Decretais gregorianas de 1234, sob o fundamento de que tais atos devem perpetuar-se nos autos, inclusive os ritualizados pelo contencioso oral (câ- nones 1.656-1.670), pois estes devem ser reduzidos a escrito pelo notário, sob pena de nulidade (cânon 1.437, §§ $1^{\circ}$ e $2^{\circ}$ ).

A fase decisória do processo, sob a regência da atual codificação em vigor, encontra-se disciplinada no Título VII, que trata genericamente "Dos Pronunciamentos do Juiz”, incluindo dentre tais as sentenças e os decretos (cânones 1607-1618). As sentenças dividem-se em sentença definitiva e sentença interlocutória como dispõe o cânone 1.607, que devem ser proferidas pelo juiz, consciente em sua mente da certeza moral sobre a questão a ser definida no provimento sentencial, determinando a lei que essa certeza deve ser haurida ex-actis et probatis (cânon 1.608, §§ $1^{\circ}$ e $2^{\circ}$ ).

A certeza moral, que é um dos requisitos internos indispensáveis da sentença canônica, resulta da inabalável convicção judicial acerca da verdade insculpida no complexo probatório (cânon 1.608). É a certeza, afirma a doutrina canônica, que exclui toda a dúvida fundada ou imaginável acerca dos fatos da causa, que elimina a probabilidade de incerteza, ainda que não a possibilidade desta vir a ocorrer. Diz-se, pois, que a certeza moral exclui a probabilidade de errar, mas não a possibilidade de ser cometido o erro. Considera que o erro é improvável, ainda que possível.

Outro requisito interno da sentença canônica é o da motivação, que na 
vigente codificação de 1983 constitui agora exigência legal expressa (cânon $1.611, \S 3^{\circ}$ ), atendendo, aliás, os reclamos da doutrina especializada na vigência das Decretais de Gregório IX, de $1234^{61}$, omissão legal que também ocorreu na primeira codificação civil oficial de 1917.

A sentença definitiva é o ato judicial que decide a questão principal, como dispõe o cânon 1.607, da codificação vigente na atualidade. Caracteriza-se como o ato culminante do processo, no qual o juiz exerce a plenitude da potestade jurisdicional de que está investido, declarando o direito em concreto como meio de satisfação do direito divino, natural ou positivo, reclamado pelo fiel ou pelo clérigo. E, a par de constituir-se a sentença definitiva no ato que transcende amplamente a ideia pura e simplesmente contida na norma positiva, é também a que ilumina as trevas da controvérsia e põe termo à demanda travada pelos litigantes.

A sentença transita em julgado após a ocorrência de duas sentenças conformes (duplex sententiae conformis) (cânon 1.641, § $1^{\circ}$ ), na vigência da codificação canônica de 1983, ra- tifica a exigência da duplicidade de sentenças conformes durante a vigência da codificação anterior de 1917 (cânon 1.902). Deste modo, o requisito das tríplices sentenças conformes, para o trânsito em julgado desse provimento decisório da demanda foi mantido pela canonística até a vigência das Decretais gregorianas, do ano de 1234, excluindo-se tal requisito a partir da codificação anterior.

A sentença viciada por errores in procedendo, isto é, viciada por nulidade insanável, é impugnada pelo recurso extraordinário da querella mullitatis (cânones 1.619-1.627), no prazo de 10 dias como ação e, permanentemente, como exceção (Canon 1.621). A sentença válida, mas injusta, que padece de errores in iudicando, está sujeita ao recurso de apelação, que se realiza em duas etapas: a primeira, no prazo de 15 dias úteis, estipulado para o apelante formular o pedido perante o juiz que prolatou a sentença (cânon 1.628-1.640); a segunda, dentro de um mês, quando o recorrente deve apresentar as razões do recurso perante o tribunal competente para julgá-lo (Canon 1.633). A sentença válida, transitada em julgado, está sujeita à

61 Acerca da motivação da sentença canônica: CRUZ e TUCCI, José Rogério. A Motivação da Sentença no Processo Civil. São Paulo: Ed. Saraiva, p. 37-47; Tratam ainda da motivação da sentença canônica: ABADIA, Jesus Lalinde. Derecho Histórico Español. Barcelona: Ed. Ariel, 1974. p. 566; GUASP, Jaime. Derecho Procesal Civil. Tomo I. Madri: Edição Institutos de Estúdios Políticos, 1968. p. 75. 
rescisão pelo recurso extraordinário da restitutio in integrum, se estiverem presentes para o seu cabimento os requisitos legais (cânon 1.645-1.648). Entre os requisitos fundamentais para embasar o recurso, devem estar a iminência de grave dano a um dos litigantes e a manifesta injustiça da sentença, como é o caso desse ato decisório ser obtido com dolo de uma parte, que venha acarretar prejuízo à outra parte. ${ }^{62}$

A sentença interlocutória constitui a categoria de provimento judicial adequado, por seu modo de atuar efeitos, para decidir uma questão incidente ou terminativa da relação processual devido às características do processo canônico de dividir o seu procedimento em termini ou stadia estanques, cada um encerrado por uma sentença interlocutória ou por um decretum.

Esse modo de atuação da canonística, que vem desde a vigência das Decretais gregorianas, transitou pela codificação de 1917 (cânones 1.840 e $1.880, \S 6^{\circ}$ ) e se mantém na atual de 1983 (cânones 1.607, 1.613, 1.617 e 1.618); foi herdado do processo germânico antigo, que tornava recorríveis as decisões referidas, para afastar a preclusão dos atos procedimentais mencionados. Esses dois atos supra referidos, que pertencem à tradição do direito da Igreja, vinham provocando perante este uma ampla recorribilidade, com sérios prejuízos para o seu andamento, de tal modo a provocar a preocupação das autoridades eclesiásticas reunidas no Concílio de Trento (1545-1563), para que optassem por realizar uma classificação das interlocutórias em senentiae interlocutoriae vim definitivam habentes e em sententiae interlocutoriae símplices, subdividindo-se as primeiras em interlocutórias terminativas do processo e em interlocutórias que causam irreparável dano ou de difícil reparação ao vencido. Como até então todas as sentenças interlocutórias eram apeláveis indistintamente, os conciliares tridentinos limitaram o recurso de apelação às primeiras e o proscreveram para as segundas, por entenderem ser estas últimas apreciáveis pelo juiz durante a marcha do processo até a decisão final, porquanto sobre elas não se operava a preclusão, conforme os cânones do mencionado Concílio, aprovados pelo Papa Paulo IV, na Bula Benedictus Deus, de 25 de janeiro de 1564.

Desse modo, na vigência do presente código Canônico de 1983, são

62 JESUS HORTAL, Padre. Código de Direto Canônico de 1983 Comentado. Trad. portuguesa. Comentários aos Cânones 1.645 e 1.648. São Paulo: Edições Loyola, 1987. p. 704-706. 
atacáveis pelo recurso de apelação, além das sentenças definitivas, que resolvem a questão principal, também as questões incidentes decididas por sentença interlocutória classificada como sentença interlocutória com força de definitiva, restando inapelável por ser revogável pelo juiz a qualquer tempo, até a prolação da sentença final, a sentença interlocutória simples, como dispõem os Cannes 1.591 e 1629 , § $4^{\circ}$.

Situação paralela a das sentenças interlocutórias é a do decretum, que na sistemática da codificação é o provimento judicial próprio para decidir ou encerrar as fases introdutória, probatória e de discussão do processo de conhecimento na primeira instância. A contrário senso, do que dispõe o Cânon 1.629, § $4^{\circ}$, só é apelável o decreto com força definitiva, restando irrecorrível o decreto de expediente ou de mero expediente.

Por fim, como já se referiu anteriormente, todas as disposições canônicas supra mencionadas dizem respeito ao Direito Canônico da Igreja Ocidental ou Latina, pois acerca do Direito Canônico Oriental ainda não há codificação própria, embora se te- nha notícias de haver propostas para a sua instituição.

\section{A HISTÓRIA DA SENTENÇA PERANTE O DIREITO PORTUGUÊS ANTIGO}

A formação da monarquia portuguesa teve, como fato precedente, o episódio da outorga da concessão do então Condado Portucalense, por Afonso VI, rei de Leão, em 1095, ao casal constituído por sua filha nascida de união extraconjugal do monarca outorgante, dona Teresa, com o nobre francês D. Henrique de Borgonha, devido ao casamento de ambos; eis que já havia confiado a Galiza a D. Raimundo, também nobre francês, em 1092, pelo casamento deste com dona Urraca, filha legítima de Afonso VI e sua sucessora no trono. ${ }^{63}$ Do casamento de dona Teresa com D. Henrique de Borgonha nasce o filho Afonso Henriques.

Em 1112, três anos após o falecimento de Dom Afonso VI, morre D. Henrique de Borgonha, e dona Teresa assume o comando do Condado Portucalense.

63 CAETANO, Marcello. História do Direito Português. v. I. n. 43, p. 136-144; n. 44, p. 177 e ss. Lisboa: Editorial Verbo, 1906; Rio de Janeiro: Editora Verbo, 1980; ALMEIDA COSTA, Mário Júlio. História do Direito Português. n. 26. Coimbra: Editora Almedina, 1989. p. 159 e ss.; GOMES DA SILVA, Nuno J. Espinosa. História do Direito Português. Lisboa: Edição da Fundação Calouste Gulbenkian, 1986. p. 99-105. 
Todavia, duraria o governo de dona Teresa apenas até o ano de 1128, pois nesta data, Afonso Henriques, que três anos antes, em Zamora, se armara de cavaleiro a si próprio-sécus moris est Regibus facere - afasta sua mãe, pela força das armas, da chefia do Condado. Possivelmente, pouco tempo antes de Afonso Henriques se tornar o único Senhor de Portugal, teria havido uma repartição territorial entre mãe e filho: Afonso Henriques teria ficado a governar ao norte do Douro e, Dona Teresa, ao sul.

A partir do ano de 1140, passa Afonso Henriques a intitular-se rei de Portugal, sendo reconhecido como tal por D. Afonso VII, mas a Santa Sé lhe reconhece apenas o título de $d u x$ e só no papado de Alexandre III (11591181), pela Bula Manifestus Probatus Est, de 1179, o monarca português recebe a dignidade real e Portugal erige-se em reinado. ${ }^{64}$

\subsection{O estágio da sentença nos primeiros séculos da monarquia}

O período de estabilização da monarquia portuguesa, não só no terreno político, mas também no plano jurídico, foi naturalmente iniciado com a fundação da nacionalidade no século XII e tem seu aprimoramento e o registro de uma relativa autonomia em meados do século XIII, quando, a partir daí e especialmente com o reinado de Afonso III (1245-1279), pode-se verificar uma acentuada tendência para a personalização do direito português, não se podendo ignorar, inclusive, que o país resultou de um desdobramento do Reino de Leão, e em razão desse fato não é de causar surpresa que as fontes do direito leonês tenham vigorado, também, no Estado português, nos primórdios de sua independência. Cabe apenas distinguir as disposições leonesas que se conservaram em vigor das que não foram acolhidas, pois é frequente a sua citação em documentos anteriores e posteriores à fundação da nacionalidade, com informações formais ou genéricas à dita codificação, designada por Lex gothorum ou forum iudicum. Na primeira metade do século XIII, com Fernando III, deu-se uma revitalização desse corpo legislativo leonês, quando recebeu a denominação de Fuero Juzgo.

As alusões a essa codificação nos alvores da monarquia portuguesa configuram-se como naturais, pois era o Código Visigótico considerado pelos historiadores o único corpo de legislação geral capaz de, ao tempo,

64 GOMES DA SILVA, Nuno J. Espinosa. Op. cit., p. 99-105; CAETANO, Marcello. Op. cit., n. 43, I e II, p. 136-139; n. 44, I, p. 177. 
servir de lastro jurídico comum ou ponto de referência dos povos peninsulares, devendo-se notar que a codificação gozou de vigência prolongada em Leão e Castela. ${ }^{65}$

A processualística, que ainda guardava muitos caracteres do sistema germânico-visigótico pautava-se pelos princípios da oralidade, da publicidade, da concentração e da lealdade, fazendo-se tudo às claras, perante a comunidade, "à luz do dia, até que o sol se pusesse no horizonte”. Para a realização da prova, recorriam frequentemente às ordálias, ou juízos de deus, segundo os quais o vencedor do duelo ou o que o suportasse e sobrevivesse aos atos cruéis, tinha a proteção divina e, em consequência, a verdade sobre os fatos alegados. Desse modo, o julgamento da causa realizava-se perante a assembleia, cuja decisão constituía mero ato homologatório do resultado da prova, aliás, característica fundamental do processo barbárico, denotando o apego às arraigadas tradições, crenças e aos costumes germano-visigóticos predominantes na época, que ainda não haviam sido superados pela novel civilização portuguesa.
Aos poucos, porém, o direito local, por meio dos forais, e o geral, mediante as leis gerais dos primeiros monarcas, foram se firmando no consenso da população, verificando-se, em contraposição, um paulatino abandono das fontes do passado, e uma progressiva integração às novas perspectivas propostas pelo novo Estado que então se instalara na Península.

Essa tomada de posição inovadora em relação ao passado foi sobremodo favorecida e impulsionada pelas novas concepções do direito canônico, emergentes das Decretais de Gregório IX, oferecidas ao povo lusitano pelas Concórdias e Concordatas com as autoridades eclesiásticas, bem como pela admissão do direito romano que então renascia como consequência da reconquista. ${ }^{66}$

A partir daí, alteram-se os modos de conceber o processo. No que pertine à prova, abandonando o sistema das ordálias e do tarifamento, passando ao sistema da sua valoração pelo juiz, segundo a sua pertinência com o objeto e as circunstâncias em que era produzida.

Os procedimentos decisórios das demandas, no período de formação do direito lusitano, operava-se por meio

65 ALMEIDA COSTA, Mário Julio de. Op. cit., p. 183-194; GOMES DA SILVA, Nuno I. Espinosa. Op. cit., p. 112-114.

66 A respeito das influências das Decretais de Gregório IX e das concórdias e concordatas das autoridades eclesiásticas no período de formação do direito português: ALMEIDA COSTA, Mário Julio de. Op. cit., p. 258-263. 
de dois institutos em geral adotados pelos sistemas jurídicos do passado e do presente, entre tais, as sentenças, divididas em sentença definitiva e em sentença interlocutória.

A sentença definitiva readquire nesse estágio de formação da processualística portuguesa todo o valor do seu tradicional conteúdo substancial e a eficácia de ato definidor da questão principal do litígio, enquanto a sentença interlocutória, de igual modo, tem restabelecida a sua função específica de resolver as questões incidentes produzidas durante o ritual do procedimento, acolhendo a processualística lusitana tal modelo de provisão judicial, que se postava na sistemática processual desde suas origens no processo romano-canônico sob a influência do antigo processo germânico.

E a importância registrada pela adoção desses dois institutos decisórios pelo antigo processo lusitano está patenteada nas definições de Jácome Ruiz, a seguir expressas, na língua vernácula antiga.

Dyffinitiva e a sentença que determinha ha principal demanda e dá acabamento a todo o pleyto assy como quando disse o juiz damos à parte por uençuda.

Interlocutoria é aquella que nõ e dada subre lla demanda principal mays subre algunas douidas que acae- çen eno pleyto assy come subre carta de persoarya e se e ualeduyra ou se nõ ou subre libello se e bem formado ou se nõ ou subre outras douidas semellaues que acaeçen e no pleyto. ${ }^{67}$

\subsection{A temática da sentença nas Ordenações Afonsivas}

Sob o governo de D. João I (13851433), no início do século XIV, deliberou a dinastia portuguesa ordenar a legislação esparsa que vinha sendo adotada desde a independência, em meados do século XII, concentrando-a em uma compilação única, destinada a atender os interesses políticos e jurídicos da nacionalidade.

É que, naquele estágio da civilização lusitana, muitos forais promulgados nas épocas de $D$. Afonso III (1245-1279) e de D. Diniz (1279-1325), ainda eram observados, concorrendo estes com as leis régias criadas desde o início da organização estatal e, ainda, com as compilações privadas elaboradas no período. A todo esse caudal de diplomas oficiais e oficiosos também se juntavam as contribuições do direito romano renascido na Península e do direito canônico renovado, a partir das Decretais de Gregório IX, promulgadas por decreto papal, no ano de 1234.

67 MERÊA, Paulo. Flores de das Leyes de Jacome Ruiz. Versão portuguesa: “Flores de Direito”. Coimbra: Imprensa da Universidade, 1918. p. 39. 
Diante, pois, de tal cópia de diplomas legislativos, aplicáveis às atividades estatais e às relações de ordem privada entre os súditos, era natural o estado de perplexidade que naquele passo era sentido pela nação portuguesa, não só quanto ao conhecimento, mas também quanto à aplicação das normas adequadas às situações experimentadas ante os mencionados acontecimentos. Era sentida a necessidade de elaborar para a monarquia uma codificação que representasse unidade legislativa, não só para reunir em consolidação os textos legais do passado ainda com aplicação eficaz, como para abrigar disposições novas, então desejadas pela comunidade nacional. Era necessária, por fim, para estabelecer uma determinada hierarquia de fontes entre o diploma pátrio e as contribuições recebidas de sistemas jurídicos alienígenas, especialmente do direito romano e do direito da Igreja. ${ }^{68}$

Foi diante de tais circunstâncias que D. João I (1385-1433) encarregou a João Mendes a elaboração de uma compilação das leis em vigor, a partir do reinado de Afonso II (1211-1223). Com a morte de D. João I (1385-1433), seu filho D. Duarte (1433-1438), continuou o trabalho e o entregou aos misteres de Rui Fernandes. Morto D. Duarte, logo depois, foi a tarefa prosseguida durante a regência de D. Pedro, em face da minoridade de D. Afonso V (14461481), havendo o autor considerado o encargo concluído em 28 de julho de 1446, na Villa da Arruda, hoje Arruda dos vinhos.

Após revista e emendada por uma comissão de juristas, dentre os quais o próprio autor, Lopo Marques, Luís Martins e Fernão Rodrigues, foi o diploma promulgado, provavelmente em 1446, ou um ano depois, em 1447, ainda antes de D. Pedro deixar a regência. Atribuída à obra então realizada a D. Afonso V (1446-1481), foi-lhe conferida a denominação de Ordenações Afonsinas. ${ }^{69}$

A codificação obedeceu à estrutura das Decretais de Gregório IX, promulgadas dois séculos antes, dividindo-se, como aquelas, em cinco livros que eram subdivididos em títulos. As regras pertinentes ao processo civil estavam dispostas no Livro III, que estava subdividido em 128 títulos.

As sentenças estavam disciplinadas nos Títulos 67 a 70 do Livro III, que se dividiam, em sentenças definitivas (III, 69) e em sentenças interlocutórias (III, 67), observando o códi-

68 GOMES DA SILVA, Nuno J. Espinosa. Op. cit., p. 185-193.

69 ALMEIDA COSTA, Mário Julio de. Op. cit., p. 269-271. 
go afonsino a classificação realizada a partir da prática do processo comum italiano do século VII, época em que foi criada a sentença interlocutória sobre a prova ${ }^{70}$, com a formidável ampliação que lhe foi dada pelo processo alemão e canônico intermédios. ${ }^{71}$

A sentença definitiva projetava-se no código afonsino como o provimento judicial de conteúdo substancial, que resolvia a questão principal pondo termo ao litígio e encerrando a relação processual travada entre os contendores. Era decretada a sua irrevogabilidade como regra, mas permitia-se-lhe fosse corrigida de imperfeições materiais, quando contivesse palavras escuras e intrincadas (III, 67,4). Do mesmo modo, era permitido fossem supridas, por meio de recurso, omissões formais do procedimento, com a finalidade de evitar nulidade e perda do processo com prejuízo para as partes (III.68.3 a 6).

Estava também vedada pela ordenação a prolação de sentença extra e citra petita, ao dispor que o juiz devia proferir a sentença em estrita conformidade com o pedido do autor e a defesa do réu (III.69.1). Era, ainda, vedado ao juiz prolatar sentença incerta, quando se tratasse de pedido certo, permitindo-se, porém, a sentença condicional, nos casos em que a Ordenação o permitisse (III.69.2).

A sentença interlocutória, que era admitida pela codificação afonsina, estava dividida em sentença interlocutória simples e em sentença interlocutória mista, segundo a prática que já vinha sendo admitida no direito intermédio. Acerca da primeira, não era admitido o recurso de apelação, por ser de caráter exclusivamente processual, ao passo que a segunda era recorrível pelo dito recurso, conforme autorização em lei de D. Afonso IV (1325-1357).

\subsection{A evolução da sentença nas Ordenações Manuelinas}

Embora tivessem as Ordenações Afonsinas solucionado os problemas da disseminação das legislações esparsas, que vinham sendo adotadas desde os primeiros tempos do novel império português, reunindo-as em codificação única, experimentou a referida codificação uma curta duração, eis que já em 1505, criava D. Manuel (1495-1521) uma comissão composta por destacados juristas para reformar o estatuto anterior. Dita comissão fora

70 CHIOVENDA, Giuseppe. Ensaios de Derecho Procesal Civil. Trad. espanhola. v. III. Buenos Aires: Ediciones Jurídicas Europa-América (EJEA), 1949. p. 251.

71 BUZAID, Alfredo. Do Agravo de Petição no Sistema do Código de Processo Civil. n. 5-6. 2. ed. São Paulo: Saraiva, 1956. p. 23-24. 
composta por Rui Boto, Rui da Grã e João Cotrim, com a missão ampla de realizarem o que fosse necessário para o sucesso do empreendimento.

Acerca dos móveis que levaram o monarca determinar a realização da nova codificação estavam, na época, cercados de conjeturas, tais como uma melhor divulgação da obra com a descoberta da imprensa em fins do século XV, que ensejaria melhor divulgação do estatuto no seio da população, sendo de toda conveniência que o fosse atualizado; a de que o empreendimento estaria ligado à empolgação de D. Manuel em razão dos eventos culturais, artísticos e científicos que contemporaneamente se realizavam na Europa; e, por fim, o desejo do monarca ter seu nome ligado a uma obra jurídica de tomo, que entendia necessária, à realização da justiça. ${ }^{72}$

Há suposições fortes de que as Ordenações Manuelinas teriam sua primeira edição publicada já em 1514, havendo como principal argumento em favor dessa hipótese a existência de uma ordem de pagamento passada pelo Rei ao livreiro-editor Valentim
Fernandes Alemão, naquela data. ${ }^{73}$ No entanto, a versão até hoje oficial é a de que foram as Ordenações publicadas integralmente no ano de 1521.

Trouxe a codificação manuelina grandes transformações de forma e de conteúdo em relação à anterior, pois enquanto no estatuto afonsino era feita a transcrição integral dos textos legais anteriormente compilados, para após serem confirmados, alterados ou revogados, nas ordenações de D. Manuel foi usado o estilo decretatório, sendo a matéria versada originariamente, isto é, como se se estivesse legislando naquela oportunidade pela primeira vez. ${ }^{74}$

Quanto à sua estrutura, a codificação manuelina em nada difere da afonsina. Foi distribuída em cinco livros, sendo estes subdivididos em títulos e também em parágrafos.

O processo civil continuou a ser tratado no Livro III, que foi dividido em noventa títulos. De um modo geral, a matéria processual afastou-se um pouco mais das linhas do processo comum, em relação a codificação antecedente, ainda assim, a ordem do juízo foi parcialmente afetada pelo

72 Sobre o assunto: ALMEIDA COSTA, Mário Julio de. Op. cit., p. 276-277.

73 Sobre o assunto: BRACA DA CRUZ, Guilherme. O Direito Subsidiário na História do Direito Português, n. 7, nota 1, p. 309-335. In: Obras Esparsas. v. II. Coimbra: Editora Coimbra, 1981.

74 BRAGA DA CRUZ, Guilherme. História do Direito Português. Coimbra: Ed. Editora Coimbra, 1955. p. 390-392; AZEVEDO, Luiz Carlos de. O Direito de Ser Citado. São Paulo: Edição FIEO, Editora. Resenha Universitária, 1980. p. 287-296. 
formalismo do direito comum do século XIII.

No que pertine às sentenças, disciplinadas nos Títulos 48 a 52 da mencionada codificação, há uma desordenada sistematização da matéria, pois a sentença definitiva, que resolve o mérito, qualificada como a principal provisão do juiz no âmbito processual, encontra-se disciplinada posteriormente à sentença interlocutória, repetindo-se o equívoco verificado também na codificação afonsina, em que havia inversão topológica entre a decisão final de mérito e a interlocutória incidente e intermediária.

A sentença definitiva, no código manuelino, declarava e textualmente ratificava a sua qualidade e eficácia de sentença de mérito, pois em realidade estava configurada nessa provisão judicial, quanto ao seu conteúdo, a questão principal da demanda, que já vinha sendo como tal considerada pela doutrina e pelas legislações anteriores em geral. E, para obter tais objetivos, devia o juiz observar integralmente o respectivo rito procedimental e, bem assim, analisar com seguro critério os fatos invocados pelo autor e pelos contraditados pelo réu, em face do complexo probatório, para produzir uma decisão justa. Em contraposição, era-lhe vedado proferir sentença extra petita, porque só ao Príncipe conferia a lei da faculdade de julgar segundo a sua consciência (III. 50.pr.).

Ao prolatar a sentença devia o juiz condenar o vencido ao pagamen- to das custas processuais em favor do vencedor (III.51), continuando o código manuelino a contemplar o princípio da sucumbência, já acolhido nas Ordenações Afonsinas.

A sentença interlocutória, que já vinha sendo acolhida pelos sistemas processuais anteriores, destinava-se a decidir as questões incidentes que se plantassem no transcurso do procedimento e foram, de igual modo, adotadas pelo código manuelino, acolhendo este a divisão em sentença interlocutória simples e em sentença interlocutória mista, assim classificadas por decisões do Concílio de Trento da Igreja Católica (1545-1563), que restaram aprovadas pelo Papa Paulo IV, na Bula Benedictus Deus, de 25 de janeiro de 1564.

Nas Ordenações de D. Manuel, seguindo a linha tradicional estabelecida pelas legislações anteriores, eram recorríveis mediante o recurso de apelação tanto as sentenças definitivas como as sentenças interlocutórias mistas, restando irrecorríveis as sentenças interlocutórias simples, práticas que também já vinham sendo ocorridas no passado.

\subsection{O trânsito da sentença nas Ordenações Filipinas}

Após à promulgação do Código Sebastiânico e ainda vigentes as Ordenações Manuelinas, surgiram as leis de 18 de novembro de 1577 e ou- 
tra de 1582, que alteraram sensivelmente a ordem dos juízos, derrogando a lei de D. João III (1521-1557), sobre a matéria naquela codificação compilada. Antes, porém, já havia-se realizado o Concílio de Trento (15451563), no qual se manifestara pelos conciliares uma profunda preocupação da Igreja em reformar o Direito Canônico com o objetivo de fortalecer as instituições religiosas. As transformações assim votadas e aprovadas acerca da canonística foram recebidas em Portugal, devido às ligações de D. João III (1521-1557) com o clero e a presença na Corte do Cardeal D. Henrique (1578-1580), proclamado rei de Portugal, após a morte de D. Sebastião (1568-1577), neto de D. João III, em Alcácer Quibir, no ano de 1577.

Todavia, a interferência acentuada da influência canônica derivada do Concílio tridentino começava a criar obstáculos ao direito português, no âmbito da administração da justiça, recomendando a realização de uma reforma nesse setor da vida nacional. Foi assim que, assumindo D. Felipe II de Espanha e I de Portugal o governo português, devido à morte de D. Sebastião (1568-1577), e logo em seguida a do Cardeal D. Henrique, nomeava o novo monarca uma comissão de juristas composta por Jorge Cabedo, Afonso Vaz Tenreiro e Duarte Nunes do Lião, em 1581, para a elaboração de novas Ordenações. Foram os trabalhos iniciados entre 1583 e 1585, segundo as conjecturas mais aceitas.

A nova codificação ficara concluída em 1595, e por lei de 5 de junho de 1595 recebia aprovação, mas esse ato não chegou a produzir efeitos. Passados mais oito anos, já então sob o reinado de Felipe II de Portugal e III de Espanha, e por lei de 11 de janeiro de 1603, era a nova compilação promulgada sob a denominação de Ordenações Filipinas.

O novo diploma legislativo declarava revogadas todas as normas legais não incluídas na compilação, ressalvadas as transcritas em livro conservado na Casa da Suplicação, das Ordenações da Fazenda e dos Artigos das Sisas. ${ }^{75}$

Pretenderam os compiladores do código Filipino uma simples atualização das Ordenações Manuelinas, mas o trabalho de transposição da antiga para a nova codificação não obedeceu a uma formulação adequada, daí restarem subsistentes normas revogadas ou caídas em desuso, falta de clareza em disposições remodeladas, bem como contradições entre normas novas incluídas e normas antigas que não foram eliminadas. A falta de originalidade e os defeitos apresentados pela codificação rece-

75 ALMEIDA DA COSTA, Mário Julio de. Op. cit., p. 285-287. 
beram a designação de filipismos, em fins do Século XVIII, havendo o apelido acompanhado até o final de sua vigência. ${ }^{76}$

As Ordenações de Felipe II seguiram o sistema tradicionalmente adotado pelas anteriores, mediante a divisão em cinco livros, estes subdivididos em 98 títulos e parágrafos.

O processo civil encontrava-se ordenado no mesmo sistema das ordenações portuguesas anteriores, como regra geral, disciplinado no Livro III da codificação, apresentando quatro tipos de procedimentos: o procedimento ordinário, o procedimento sumário, o procedimento sumaríssimo e os procedimentos especiais. Cada um deles ritualizava-se mediante modos e formas diversas, segundo o tipo de demanda, seu valor maior ou menor e as categorias dos direitos e interesses das partes a serem tutelados.

As sentenças estavam classificadas em sentenças definitivas e em sentenças interlocutórias, seguindo, de igual modo, as experiências que já vinham sendo adotadas desde as codificações canônicas, herdadas estas do processo germânico antigo, como anteriormente foi neste trabalho referido.

As sentenças definitivas eram, na codificação de D. Felipe II, as pro- visões judiciais que definiam e decidiam a questão principal da demanda e encerravam a relação processual travada pelas partes. Eram proferidas pelo juiz pela forma escrita, em todos os tipos de procedimento, ou seja, no ordinário (III, 20), no sumário (III, 30.1), no sumaríssimo ou verbal (I.65.7) e nos especiais (III.25.pr.), amparando-se a decisão na prova colhida e valorada, segundo os elementos constantes nos autos, ou, como dito na linguagem da época, segundo a verdade que nos processos for provada e sabida. No que concerne ao conteúdo, devia a sentença ser certa e determinada, expressando-se nos limites da demanda, em obediência ao princípio de que sententia debet esse conformis libello. E, por adotarem tal orientação, as Ordenações de D. Felipe II vedavam expressamente ao juiz prolatar sentença ultra, extra petita e citra petita e, como tais, consideradas anuláveis. Além desses requisitos, era de igual modo exigida a presença do requisito interno da motivação (III.66.7)..$^{77}$

À sentença definitiva anulável, era dada pelo código filipino, em geral, a mesma solução das Ordenações anteriores, pois nesse caso a sentença não será considerada per Direito ne-

76 ALMEIDA DA COSTA, Mário Julio de. Op. cit., p. 287-288.

77 Sobre o tema: CRUZ e TUCI, José Rogério. Op. cit. p. 50-51. 
nhuma, mas he valiosa. Em razão disso, devia ser impugnada pelo recurso de apelação pelo interessado no prazo de 10 dias, para impedir que viesse a produzir a eficácia de sentença válida e firme (III.75.2).

Inobstante, não resultava anulável a sentença pronunciada com palavras escuras ou intrincadas, pois, nesse caso, a decisão poderia ser corrigida pelo juiz prolator ex officio, ou mediante pedido da parte interessada (III.66.6).

Adotando disposição legal semelhante a que se continha nas codificações afonsinas e manuelinas, as Ordenações de D. Felipe II admitiam o benefício comum no juízo de apelação, o que significava oportunizar uma reformatio in peius contra o apelante e em favor do apelado (III.72.pr.).

A sentença proferida pelos juízes ou pelos ouvidores, devido à alta hierarquia de que estavam investidos, não era apelável, mas sujeita ao recurso de agravo ordinário, que anteriormente se chamou sopricação (III.84).

Nas Ordenações Filipinas, a sentença em que o juiz, ao proferi-la, tivesse se fundado em falsa prova ou a tivesse sido prolatada por juiz subornado ou peitado, estava sujeita ao recurso de revista de justiça, ou à revista de graça especial, fundada exclusivamente na autoridade e mercê do rei, na qualidade de juiz supremo (III.95.pr.).

As sentenças interlocutórias, que se destinavam a decidir as questões incidentes que se plantavam no transcurso do procedimento, foram, a exemplo e semelhança das ordenações portuguesas anteriores, divididas em sentenças interlocutórias simples e em sentenças interlocutórias mistas, sendo estas últimas subdivididas em sentenças interlocutórias terminativas e em sentenças interlocutórias causadoras de dano irreparável ao vencido.

As sentenças interlocutórias simples, que se tornaram irrecorríveis pelas decisões do Concílio de Trento (1545-1563), no âmbito da canonísti$\mathrm{ca}$, e $a b$ initio no contexto do direito lusitano, com a lei de D. Afonso IV (1325-1357), passaram, quando não revogadas pelo juiz prolator, a ser impugnadas a partir das Ordenações Manoelitas pelos recursos de agravo de instrumento e de agravo de petição, fazendo-se a distinção entre esses dois recursos pelo critério geográfico ou territorial das cinco léguas da sede do juízo a quo ao juízo ad quem (III.65). ${ }^{78}$

78 Sobre este tema: NORONHA, Carlos Silveira. Do Agravo de Instrumento. 3. ed. Rio de Janeiro: Forense, 1995. p. 27-28. 
As sentenças interlocutórias mistas, no regime da codificação filipina, mantiveram a situação anterior, pois continuavam a ser impugnadas pelo reurso de apelação, tanto as terminativas do processo (III.65.1), como as causadoras de dano irreparável ao vencido (III.65.5).

Esgotadas as vias recursais ou na hipótese de ser a decisão irrecorrível, ou, ainda, se o vencido viesse a aquiescer à sentença que lhe fosse gravosa, transitava em julgado a decisão, tornando-a firme e imutável.

As Ordenações Filipinas, apesar de haverem sido promulgadas por um monarca espanhol, D. Felipe II, de Portugal, e D. Felipe III, de Espanha, que na época reinava sobre o Império Português, sobreviveram à Revolução de 1640, que restaurou o Reino de Portugal quando D. João IV confirmou toda a legislação castelhana, sendo o Código Filipino expressamente revigorado pela lei de 29 de janeiro de $1643 .{ }^{79}$

As Ordenações de D. Felipe II constituiram-se na codificação da mais extensa vigência no reino português, pois estiveram em vigor no país de origem até a edição do Código Civil Lusitano de $1^{\circ}$ de julho de 1867. No Brasil, regeram os destinos do nosso País no período colonial até a Independência, em 7 de setembro de 1822, e, a partir da independência, prolongaram sua vigência, quando a Assembleia Constituinte e Legislativa nomeada por D. Pedro I, em data de 3 de maio de 1823, promulgava uma lei de 20 de outubro de 1823, determinando a vigência das Ordenações Filipinas para reger a vida deste País, até que leis nacionais próprias fossem pelo novo Estado organizadas e aprovadas. Como a primeira codificação civil brasileira foi editada em janeiro de 1916, com vacatio legis até $1^{\circ}$ de janeiro do ano seguinte, a codificação filipina restou em vigor em nossa pátria até 31 de dezembro de 1916, referentemente à área de Direito Civil material ou substantivo (como dizem alguns), então disciplinada no Livro IV da mencionada codificação portuguesa. ${ }^{80}$

79 BRAGA DA CRUZ, Guilherme. Op. cit., p. 394-400; ALMEIDA COSTA, Mário Julio de. Op. cit., p. 287-289.

80 ALMEIDA COSTA, Mário Julio de. Op. cit., p. 285, nota 2; p. 288; NORONHA, Carlos Silveira. Sentença Civil. Perfil Histórico-dogmático. São Paulo: Revista dos Tribunais (RT), 1995. p. 250-251. 


\section{REFERÊNCIAS}

ABADIA, Jesus Lalinde. Derecho Histórico Espanhol. Barcelona: Edição Ariel, 1974.

ALCALÁ-ZAMORA Y CASTILLO, Niceto. Estudio de Teoria General e Historia del Proceso. Tomo II. México: Edição UNAM, 1974.

ALMEIDA COSTA, Mário Julio de. História de Direito Português. Coimbra: Editora Coimbra, 1989. ARÂNGIO-RUIZ, Vicenzo. Instituciones de Derecho. Trad. espanhola. Buenos Aires: Edição Depalma, 1952.

. Storia del Diritto Romano.

Casa Editrice Dott. Eugenio Jovene. Napoli, 1985.

ARIAS, José V. Salazar. Dogmas y Cánones de la Iglesia em el Derecho Romano. Madrid: Ed. Instituto Editorial Réus, 1954.

AZEVEDO, Luiz Carlos de. O direito de ser citado. Edição FIEO. São Paulo: Editora Resenha Universitária, 1980.

BETTI, Emilio. Istituzioni di Diritto Romano. v. I, §§ 102-103, p. 346351. Padova: Ed. CEDAM, 1942. BIONDO BIONDI. Appunti Intorno alla Sentenza nel Processo Civile Romano. In: Scritti Giuridici II. Milano: Ed. Giuffrè, 1965.

BISCARDI, Arnaldo. Diritto Greco Antico. Milano: Ed. Giuffrè, s/ data.
. Lezioni sul Processo Romano Antico e Clássico. Turim: Ed. Giappichelli Editore, 1968.

BRAGA DA CRUZ, Guilherme. O Direito Subsidiário na História do Direito Português. In: Obras Esparsas. v. II. Coimbra: Ed. Coimbra, 1981.

BRAGA DA CRUZ, Guilherme. História do Direito Português. Coimbra: Editora Coimbra, 1955.

BÜLLOW, Oskar von. Ecepciones Procesales y Presupuestos Procesales. Buenos Aires: Ediciones Juridicas Europa-América (EJEA), 1964.

BUZAID, Alfredo. Do Agravo de Petição no Sistema do Código de Processo Civil. São Paulo: Saraiva, 1956.

CAETANO, Marcello. História do Direito Português. Lisboa: Editorial Verbo, 1980.

CALAMANDREI, Piero. Opere Giuridiche. v. I. Napoli: Edicion Morano Editore, 1965.

CANNATA, Carlo Augusto. Profilo Istituzionale del Processo Privato Romano. I Legis Actiones. Turim: Giappichelli Editore, 1980. . Profilo Istituzionale del Processo Privato Romano. II Processo Formulare. n. 1, p. 1-2. Turim: Ed. Giappichelli Editore, 1982. . Profilo Istituzionale del Processo Privato Romano. II Proces- 
so Formulare. n. 2, p. 3-4; n. 4, p. 7-11; n. 12-14, p. 46-67; n. 20, p. 51-57; n. 38, p. 163-165; n. 40, p. 175-187, nota 2.

CHIOVENDA, Giuseppe. Ensayos de Derecho Procesal Civil. Trad. espanhola. v. III. Buenos Aires: Ediciones Juridicas Europa-América (EJEA), 1949.

CÓDIGO DE HAMURABI. Babilonia. Texto traduzido em Português. Uberaba, Minas Gerais: Editora Vitória, s/d.

COSTA, Emilio. Profilo Storico del Processo Civile Romano. Roma: Ed. Athenauem, 1918. Storia delle Fonti del Diritto Romano. Milano-Turim: Ed. Fratelli Booca Editore, 1909.

COUTO e SILVA, Clóvis Verissimo do. O Direito Civil Brasileiro em Perspectiva Histórica e Visão de Futuro. In: revista Ajuris, da Associação dos Juízes do Rio Grande do Sul, ano XIV, jul. 1987, n. 40, Porto Alegre.

COUTURE, Eduardo J. Fundamentos del Derecho Procesal Civil. n. 176. 3. ed. Buenos Aires: Ediciones Depalma, 1973. . Vocabulário Jurídico. Buenos Aires: Ediciones Depalma, 1976. p. 537-538.

CRUZ e TUCCI, José Rogério. Jurisdição e Poder. São Paulo: Edição Saraiva, 1987.

Da Reconvenção. São Paulo: Edição Saraiva, 1984.
A Motivação da Sentença no Processo Civil. São Paulo: Edição Saraiva, 1987.

CUENCA, Humberto. Processo Civil Romano. Ediciones Jurídicas Europa. Buenos Aires: América (EJEA), 1957.

DE FRANCISCI, Pietro. Sintesis Historica del Derecho Romano. Trad. espanhola de Ursicino Alvarez. Madrid: Ed. Revista de Derecho Privado, 1954.

DE PAGE, Henri de. Traité de Droit Civil Belge. Tome VI. Bruxelles, 1942.Apud: GILISSEN, John, op. cit., Introdução, p. 13.

DELLA ROCCA, Fernando. Instituciones de Derecho Procesal Canónico. Trad. espanhola. Buenos Aires: Ed. Deselée de Brouwer, s/data. . Saggi di Diritto Processuale e Canonico. Appunti sul Gravami nel Processo Canonico. Padova: Ed. CEDAM, 1969.

DINAMARCO, Cândido Rangel. Tutela Jurisdicional. Separata da Revista Forense, v. 334, p. 25, Cia. Editores Forense, Rio de Janeiro.

DOMINGUEZ, Lorenzo Miguélez et al. Código de Derecho Canónico Comentado (de 1917). Madrid: Biblioteca de Autores Cristianos (BAC), 1976.

ECHEVERRIA, Lamberto et al. Código de Derecho Canónico (de 1983). Prefácio. Edición comentada bilíngue (latim-espanhol). Madrid: Ed. Biblioteca de Autores Cristianos (BAC), 1985. 
ENRIQUES, Enzo. La Sentenza Come Fatto Giuridico. Padova: Ed. CEDAM, 1937-XV.

FRANCA, La Rosa. L'actio Iudicati nel Diritto Romano Classico. Milano: Edizione Giuffrè, 1963.

GAYO. Instituciones. Edición Bilíngue (latim-espanhol). Trad. espanhola: Manuel Abellan Velasco et al. Madrid: Edição Civitas, 1985.

GILISSEN, John. Introdução Histórica ao Direito. Trad. portuguesa: A. M. Espanha; L. M. Macaista Malheiros. Lisboa: Ed. Fundação Calouste Gulbenkian, 1985.

GIOMARO, Anna Maria. La Tipicitá delle Legis Actiones e La Nominatio Causae. Milano: Ed. Giuffrè, 1988.

GOMES DA SILVA, Nuno J. Espinosa. História do Direito Português. Lisboa: Ed. Fundação Calouste Gulbenkian, 1986.

GUASP, Jaime. Derecho Procesal Civil. Tomo I. Madrid: Edição Instituto de Estúdios Políticos, 1968.

HERNANDEZ, Miguel Moreno. Derecho Procesal Canónico.Madrid: Editora Aguilar, 1956.

ITÁLIA. Codice Civile e Leggi Collegate. Libro Sesto: Della Tutela dei Diritti. Bologna: Ed. Zanichelli, 2007. p. 446-491.

JESUS HORTAL, Padre. Código de Direito Canônico de 1983 comentado. Trad. portuguesa. Comen- tários aos cânones 1.645 e 1.648 . São Paulo: Edições Loyola, 1987. p. 704-706.

LÉVY-BRUHL, Henri. Recherces sur les Actiones de la Loi. Paris: Edicion Sirey, 1960.

LIEBMAN, Enrico Tullio. Appunti Sule Impugnazioni. XIII Ristampa. Milano: Ed. Cesalpino-Galliardica, 1961.

LUZZATTO, Giuseppe Ignacio.Procedura Civile Romana. Parte II - Legis Actiones. Bologna: Ed. UPEB del Dott. Cesare Zuffi, 1948.

Il Problema d'Origine del Processo Extra Ordinem. Bologna: Ed. Casa Editrice Prof. Ricardo Patron, 1995.

MARTINS GIGANTE, José Antonio. Instituições de Direito Canónico. v. I-II. Braga: Ed. Escola Tip. da Oficina São José, 1951.

MERÊA, Paulo. Flores de das Leyes de Jacome Ruiz. Versão portuguesa: "Flores de Direito". Coimbra: Imprensa da Universidade, 1918. p. 39.

MERRYMAN, John Henry. La Tradición Juridica Romano-Canónica. Trad. espanhola: Carlos Sierra. México: Ed. México Fundo de Cultura, 1971.

NORONHA, Carlos Silveira. Repensando a Tutela dos Direitos. In: Revista da Faculdade de Direito da UFRGS. v. 32. Porto Alegre: Editora Sulina, 2014. p. 76-97. 
A “Actio Iudicati” - Um Instrumento de Humanização da Execução. In: ÁLVARO DE OLIVEIRA, Carlos Alberto (org.) et al. In: O processo de ехесução: Estudos em Homenagem ao Professor Alcides de Mendonça Lima. Porto Alegre: Ed. Sérgio Antonio Fabris Editor, 1995. p. 95-126.

Do Agravo de Instrumento. 3. ed. Rio de Janeiro: Forense, 1995. . Sentença Civil: Perfil Histórico-dogmático. São Paulo: Revista dos Tribunais (RT), 1995.

PALAZZOLO, Nicola. Processo Civile e Política Giudiziária del Principato. Turim: Ed. Giappichelli Editore, 1980.

PAOLI, Ugo Enrico. Studi Sul Processo Áttico. Padova: Ed. Cedam, 1933.

PELLEGRINO, Piero. II Provedimenti Interlocutori nella Teoria Canonistica delle Impugnazini. Padova: Ed. CEDAM, 1969.

PONTES DE MIRANDA, Francisco Cavalcante. Tratado de Direito Privado. Parte Geral, Tomo I,
Prefácio. Rio de Janeiro: Edição Borsoi, 1970. p. XV. - Comentários ao Código de Processo Civil de 1973. Tomo I, Rio de Janeiro: Editora Forense, 1973.

PRATA, Edson. História do Processo Civil e sua Projeção no Direito Moderno. Rio de Janeiro: Editora Forense, 1987.

ROCCO, Alfredo. La Sentencia Civil. Trad. espanhola. n. 12. México, D.F.: Ed. Cardenas Editor y Distribuidor, 1985.

SCHIALOJA, Vittorio. Corso di Istituzioni di Diritto Romano. Roma: Ed. Anonima Romana Editoriale, 1908. . Procedimiento Civil Romano. Trad. espanhola. Buenos Aires: Ediciones Jurídicas Europa-América (EJEA), 1954.

SURGIK, Aloisio. Compêndio de Direito Processual Canônico. Curitiba: Edição Livro é Cultura, 1988.

ULHOA CINTRA, Geraldo de. História da Organização Judiciária e do Processo Civil. Tomo I. São Paulo/Rio de Janeiro: Editora Jurídica e Universitária Ltda., 1970. 